\title{
Prevalence, Barriers, and Interventions related to Medication Adherence Among Patients Diagnosed with Major Depressive Disorder: A Scoping Review
}

\author{
Anas Khalifeh ${ }^{1}$ and Ayman Hamdan-Mansour ${ }^{2}$ \\ ${ }^{1}$ Jordan Ministry of Health \\ ${ }^{2}$ Al-Ahliyaa Amman University Faculty of Nursing
}

June 8, 2020

\begin{abstract}
Background: Adherence to psychotropic medication is still a concern to health care systems, mental healthcare professionals, researchers, and patients, as well. Recent literature on medication adherence increased focusing on the pervasiveness and significant impacts of adherence to medications. Purpose: The purpose of this scoping review is to identify the prevalence, contributing factors, methods of measurement, and interventions related to medication adherence among patients diagnosed with Major Depressive Disorders (MDD). Methods: Preferred Reporting Items for Systematic Reviews and Meta-Analyses Extension for Scoping Reviews (PRISMA-ScR) guideline was used. The scoping review involves the review, analysis, and synthesis of a broad scope of literature. Results: A total of 36 articles met the inclusion criteria for this scoping review. The prevalence of medication adherence among patients diagnosed with MDD ranged from $10.6 \%$ to $85.4 \%$. About $67 \%$ of studies used self-reports as methods of data collection. Illness-related factors (e.g., the onset of the illness, duration of illness, symptoms, and illness severity), medication-related factors (e.g., adverse reactions, duration of treatment, cost of treatment), and patientrelated factors (e.g., beliefs, attitudes, knowledge, self-stigma) were the most reported factors to associate with medications adherence. Also, the multi-faceted intervention has been recommended over a single-element intervention to enhance medication adherence. Conclusion: There is a need to select and integrate good assessment measures of medication adherence, which lead to providing better evidence on the outcomes, risk factors, and interventions to improve medication adherence.
\end{abstract}

\section{Introduction}

Despite decades of researches, adherence to medication is still a widely acknowledged and persistent concern for the health care systems, healthcare professionals, researchers, and patients, as well. ${ }^{1}$ The increased literature on medication adherence has focused primarily on the pervasiveness and significant impact of adherence to medications on healthcare outcomes. ${ }^{2}$ According to World Health Organization (WHO), medication adherence is defined as "the extent to which a person's behaviour-taking medication, following a diet, and/or executing lifestyle changes, corresponds with agreed recommendations from a health care provider". ${ }^{3}$ While adherence acknowledged benefits and positive impacts on the health of patients, nonadherence medication has been reported to cause multiple forms of negative healthcare outcomes. ${ }^{4}$ In general, an overabundance of the literature suggests that patients do not adhered strictly to the drug regimen as recommended by their primary care providers. ${ }^{5}$

Although medication adherence introduced as a core function of care providers in education and discharge planning, nonadherence to medications is widely observed, causing negative healthcare outcomes and poor prognosis, in particular, among patients with chronic diseases. ${ }^{6}$ According to Jafari Oori et $\mathrm{al}^{5}, 50 \%$ of patients with chronic illnesses have poor medication adherence. Recent studies across multiple chronic conditions reported that nonadherence to medication range from $7.5 \%$ to $96 \%{ }^{6-8}$ For patients suffering from 
psychiatric disorders, nonadherence has been reported with more significant figures. For example, Gebeyehu and colleagues ${ }^{9}$ reported that $55 \%$ of patients with psychiatric disorders have a high level of medication nonadherence inferring poor prognosis and early relapse.

Depressive disorders are the most common psychiatric conditions affecting 300 million around the world. ${ }^{10}$ Major depressive disorder (MDD), is the most serious forms of depressive disorders, and also becoming a common chronic and recurrent psychiatric disorder. ${ }^{11}$ MDD is characterized by impairments of social, occupational, educational, and cognitive functioning. ${ }^{12}$ MDD is recognized as a growing global disease burden and one of the leading causes of morbidity, mortality, and economic burden. ${ }^{11}$ Annually, $6 \%$ of adults suffer from MDD worldwide. ${ }^{13}$ By 2010, MDD has become the second leading contributor to the global disability disease. ${ }^{14}$ In addition, MDD will affect at least 350 million people by 2030, which expected to become the most leading cause of disability. ${ }^{15}$

Despite the existence of effective treatments, successful treatment, and response remain sub-optimal. ${ }^{16}$ Over 20 years, adherence to medications in MDD has been an intractable clinical challenge. ${ }^{17}$ Despite the high rate of medication nonadherence, there is a variation of adherence rate related to various methods used to measure medication adherence including self-reported, pill counts, pharmaceutical claims, biomarkers, physiological measures, and electronic medication monitoring. ${ }^{4,18}$ Moreover, adherence to medication has been influenced by complex and multidimensional factors as barriers to reach successful treatment that includes patientrelated, therapy-related, healthcare system, condition-related, and socioeconomic factors. ${ }^{3,19}$ The literature has also identified a number of factors that may cause high rates of nonadherence to medication such as low education level, adverse side effects, uncertainty about treatment benefits, lack of education about medication, erroneous beliefs about the illness or medication, costs of medications, stigma, forgetfulness, lack of social support, and a negative relationship with the health care provider. ${ }^{21-25}$ The complex situation and interferences between medical, psychological, environmental factors, as aforementioned, might be proposed as the underlying reason for medication adherence among patients diagnosed with MDD.

Nonadherent patients with MDD have a high risk of relapse and recurrence, rehospitalization, decreased reduction in the severity of depression, and growing suicidal ideation. ${ }^{16,25}$ Although, previous literature has pointed out to optimize adherence to medication through designing and implement appropriate medication adherence enhancing interventions. ${ }^{22,26,27}$ Indeed, different interventions help the enhancement of medication adherence, ${ }^{28,29}$ include psychoeducation, motivational interviewing, psychosocial interventions, behavioral interventions, cognitive interventions, and cognitive-behavioral approaches. ${ }^{28,30-32}$ Various health care providers have provided these interventions includes nurses, pharmacists, therapists, psychiatrists, and social workers.

Despite of high nonadherence and early discontinuation rates on patients with MDD, which earn attention toward these populations, ${ }^{33,34}$ the literature on medication adherence among patients with psychiatric has focused on schizophrenia. ${ }^{35}$ However, nonadherence contributes to unnecessary switches medication, unneeded changes in doses, initiation of unjustified adjuvant medications, and misdiagnoses of treatment-resistant. ${ }^{36}$ So, it is crucial to attention to patients with MDD. Also, focus on the prevalence of adherence, factors affect to adherence, and interventions to improve adherence, which facilitates healthcare organizations, policymakers, and research organizations in the design and implementation of medication adherence enhancing strategies. ${ }^{37}$ However, there is a need to expand the body of knowledge towards medication adherence in MDD. ${ }^{38}$ Al-Jumah et $\mathrm{al}^{23}$, reported needing further studies to investigate the effect of interventions on factors that affect medication adherence. However, there is a scarcity and rising demand for scoping review, systematic review, and meta-analysis on the level of medication adherence, factors affect to medication adherence, methods to measure medication adherence, and medication adherence interventions among patients with MDD.

Major depressive disorder (MDD) can often be treated with psychological and pharmacological approaches. ${ }^{39,40}$ Although international and national clinical practice guidelines recommend that the first line in MDD treatment is antidepressant (AD) medications, reducing the risk of relapse and recurrence by continuing $\mathrm{AD}$ medications from six months to five years after remission to prevent relapse and recurrence 
is also a significant recommendation for good practice. ${ }^{40,41}$ Expanding a better understanding of medication adherence prevalence, factors affect medication adherence, methods to measure medication adherence, and medication adherence interventions are of key importance to stakeholders, patients, healthcare providers, and policymakers. So, the purpose of this scoping review to highlight medication adherence prevalence, the factors affect medication adherence, methods measure medication adherence, and medication adherence interventions among patients diagnosed with MDD.

\section{Research Questions}

The questions guided this review are:1-What is the prevalence of medication adherence among patients diagnosed with MDD?

2-What are the most common methods used to assess medication adherence among patients diagnosed with MDD?

3-What are the factors that affect medication adherence among patients diagnosed with MDD?

4-What are interventions that have been implemented to enhance medication adherence among patients diagnosed with MDD?

\section{Method}

\section{Protocol and Registration}

The protocol of this scoping review was performed using the Preferred Reporting Items for Systematic Reviews and Meta-Analyses Extension for Scoping Reviews (PRISMA-ScR) guidelines. ${ }^{42}$ The protocol of this study has been registered prospectively with the Open Science Framework on 21 November 2019 (https://osf.io/a2jbr). This methodology is a new approach used for several reasons, to examine the extent of emerging evidence, determine the value of researches, summarize and disseminate results, and identify the gaps in knowledge. ${ }^{43}$ The scoping review involves the review, analysis, and synthesis of a broad scope of literature. ${ }^{42}$ Also, it is offering an opportunity to clarify key concepts, research gaps, enhance practice, and evidence in policymaking and research. ${ }^{42,43}$ The framework of this scoping review followed steps, identifying aims, identifying search strategies, determination of the inclusion and exclusion criteria for literature, data extraction, discussion of the findings, reconnoitering the limitations of the literature, and provide recommendation and implication from results for practice, policy, administration, education, and further research, ${ }^{42}$ as presented in PRISMA-ScR checklist (supplementary-1). Congruently of purpose and questions, the current scoping review will report the variation of medication adherence rate, types of measurement methods, factors of nonadherence to medication, and types of medication adherence enhancing interventions.

\section{Search Strategy}

The search strategy was developed by the principal author (A.K), in collaboration with the senior author (A.M), to identify relevant literature. The search of online electronic databases including, PubMed, the Cumulative Index to Nursing and Allied Health Literature (CINAHL), Medical Literature Analysis and Retrieval System Online (Medline), and Cochrane Library was conducted as the sources of information for this review. The initial search was performed on Sep $20^{\text {th }}, 2019$, and the last search was on Nov $30^{\text {th }}$, 2019. These databases were selected to be comprehensive and cover a wide range of research papers. The search was conducted using the following keywords or search terms: Medication Adherence; Compliance; Patient Compliance; Adherence; Non-Adherence; Compliance; Non-Compliance; Antidepressant Agents; Antipsychotics Agents; Psychotropic Drugs; Drug Prescriptions; Drug Therapy; Major Depressive Disorder; Depression. Keyword combinations using Boolean operators (AND \& OR), truncation, Medical Subject Headings (MeSH), and text-words (tw) were included in the search related to the purpose and research questions. All databases were interrogated using the same keywords or search terms in searches, which subjected to standardized procedures. The final search strategy for MEDLINE can be found in supplementary file 2 .

\section{Inclusion and Exclusion Criteria}


The authors (A.K and A.M) were involved in an iterative process to improve inclusion and exclusion criteria. The inclusion criteria of the selected articles in the current review were full text, published between the period of 2014 - 2019, English-language publications, involved human participants, and include studies of adult patients being treated for MDD as their primary diagnosis. The articles were relevant to major depressive disorder, medication adherence, and medication adherence enhancing interventions. Also, any type of quantitative, qualitative, and mixed methods studies included in order to consider different aspects of research designs. In addition, the articles were original research, a peer-reviewed study, or grey literature, and other relevant studies from the reference lists of the literature selected for review were included. Similarly, papers were excluded if did not meet inclusion criteria, the full-text article could not be retrieved, articles not available in the English language, did not contribute information on factors, prevalence, or interventions in medication adherence among MDD, and MDD related to secondary to traumatic brain injury, stroke, tumor, heart attack, or other non-psychiatric illness. Also, excluded letters, opinion statements, case reports, conference abstracts, editorials, commentaries, personal communications, and book chapters.

\section{Screening Process}

Forms for the screening process were developed by principle author (A.K) and senior author (A.M) reviewed and validated it. The first level of screening, title and abstract of articles were independently screened for eligibility after deleting duplicate articles by two authors (A.K and A.M) using screening form, as outline in supplementary-3. After screening the titles and abstracts, two authors (A.K and A.M) independently screened full texts of articles for eligibility and assessed also using a standardized screening form, as outline in supplementary-4. The discrepancies on inclusion/exclusion of studies were resolved by discussion and consensus. Also, authors (A.K and A.M) was screened 30 articles by screening form to evaluate the agreement.

\section{Data Charting and Quality Assessment}

Data were charted from each article independently by two authors (A.K and A.M) using a data charting sheet. This data charting sheet developed by principle author (A.K) and senior author (A.M) reviewed and validated it. The authors (A.K and A.M) was screened 15 articles by data charting sheet to evaluate the agreement and to ensure consistency with the research questions and purpose of the scoping review. Data charting was conducted using Microsoft Excel (Microsoft, Redmond, USA) spreadsheet and EndNote reference management software. The data gathered and charted from articles included articles characteristics (authors, year of publication, study location), study characteristics (the purpose of the study, study setting, number of participants, type of study, prevalence, factors, the method used to measure medication adherence, medication adherence enhancing interventions), and study findings (outcome variables, key findings). Any conflicts about data extracted were resolved by consensus.

The methodological quality of the included articles was assessed by two authors (A.K and A.M) independently. The authors used the Mixed Methods Appraisal Tool (MMAT) ${ }^{44}$ to assess quantitative, qualitative, and mixed-methods studies, resolved disagreements by discussion and consensus. This MMAT checklist consists of two screening questions and five closed questions that are applied in all relevant studies. There are 25 criteria items to assess the quality of five different types of studies (qualitative research, randomized controlled trials, non-randomized studies, quantitative descriptive studies, and mixed methods studies); each type of study contains five criteria. The overall quality score can be checked with this tool for each study included. The tool results in a methodological rating of 0, 25, 50, 75, and 100 (with 100 being the highest quality) for each study based on the evaluation of study selection bias, study design, data collection methods, sample size, intervention integrity, and analysis. ${ }^{45}$

\section{Synthesis of Results}

Data were collated and summarized in the form of text, tables, and figures. Initially, the data were summarized based on the general characteristics of the articles, such as the year of publication, study location, study setting. The results were summarized and described based on the purpose and research questions. Finally, the clinical, policy, administration, and research implications were described. 


\section{Results \\ Selection ofStudies}

The initial search of the online electronic databases yielded 1996 relevant articles, Pubmed n=638, MEDLINE $\mathrm{n}=363$, CINAHL $\mathrm{n}=128$, Cochrane $\mathrm{n}=851$, and sixteen articles revealed from the reference lists (bibliographies) from the selected articles were examined and revised to identify additional relevant articles. After the removal of 624 duplicates article, 1372 remained, then screened the 1372 title and abstract, and excluded 1243 articles based on our screening form. One hundred twenty-nine full-text articles were reviewed and assessed for eligibility. Ninety-three additional articles were excluded for the following reasons: commentary \& editorial $(n=9)$, not relevant outcomes $(n=36)$, not relevant study design $(n=9)$, other population (different psychiatric disorders and not involve MDD) $(\mathrm{n}=26)$, MDD combined with other psychiatric disorders, and MDD developed from medical disease $(n=5)$, unobtainable $(n=8)$. A total of 36 articles were met the inclusion criteria for this scoping review. This selection process is shown in the PRISMA flow chart in Figure 1. As mentioned above, the result of the current scoping review was conducted congruent with four questions about the prevalence of medication adherence, methods used to assess medication adherence, the factors affect to medication adherence, and interventions to enhance medication adherence among patients diagnosed with MDD.

\section{Characteristics of The Included Studies}

The general characteristics of the included articles are presented in Table 1. Of the 36 included articles that published between 2014 and 2019, eight articles were conducted in the United States, five articles were in India, and the other articles were conducted in Ethiopia, Saudi Arabia, France, Spain, Malaysia, Netherlands, Nigeria, Israel, China, Turkey, Nepal, South Africa, Australia, Iran, Thailand, Singapore, and Taiwan. Regarding the study designs, the majority of included articles (32) in this scoping review were quantitative study design, 23 of them were descriptive study (prospective, non-experimental, observational, retrospective cohort, Ex-post facto, cross-sectional study), and nine studies were experimental. Furthermore, three studies were qualitative study design, and one study was a mix method design. The sample size was 42,586 patients were included in this scoping review, ranging from 18 to 14,135 patients. The age varying between 18 and 88 years, and the majority of the sample was female. Twenty-nine studies recruited samples from the outpatient setting.

\section{Methodological Quality of Included Studies}

The Mixed Methods Appraisal Tool (MMAT) ${ }^{44}$ used to assess included quantitative, qualitative, and mixedmethods studies. There was a meaningful variation in the methodological quality of the included articles, with scores ranging from $25 \%$ to $100 \%$; the score of each type of study is judged within its methodological scope as presented in Table 2. Also, the distribution of study design with study quality is presented in Table 3 . The majority of studies $(\mathrm{n}=18,50 \%)$ were methodologically adequate $(>75 \%)$, noting that design and research perform were generally appropriate. Thirteen studies $(36.1 \%)$ in score $75 \%$, four studies (11.1\%) in score $50 \%$, and one study $(2.8 \%)$ in score $25 \%$.

\section{Prevalence of Medication Adherence in Patients With MDD}

The included articles investigated medication adherence to AD medications or concomitant with antipsychotics, anxiolytics, mood stabilizers, and psychostimulants medications. Although thirty-three included studies used adherence measurement methods, ten of them not measure the prevalence, which five included studies not mentioned the medication adherence level, and five included studies examined intervention. Although, the prevalence of medication adherence among patients diagnosed with MDD was found to range from $10.6 \%$ to $85.4 \%$, as presented in Table 4 , this variation depends on the data collection method used to measure medication adherence and the period of measure.

\section{Methods to Assess Medication Adherence}

The descriptions of data collection methods are presented in Table 4. Out of 33 studies used data collection 
methods to measure medication adherence, $22(66.6 \%)$ studies used a self-report data collection method, pharmacy refill and claims database 9 (27.3\%), and pill count $2(6.1 \%)$. Moreover, the selected studies used various data sources; the majority obtained from patients $(n=21)$, and direct methods were not used in the included studies. As previously mentioned the variation of the prevalence of medication adherence, the rate of adherence as assessed by using self-reported, claims database/refill data, pill count, health provider's report (self-report, patient record) ranged from $10.6 \%$ to $81 \%,{ }^{19,21-23,34,46-62} 10 \%$ to $62.9 \%,{ }^{25,34,63-70} 45 \%,{ }^{71,72}$ and $69.2 \%$ to $85.4 \%,{ }^{34,58}$ respectively. The most common included studies utilized standardized and structured data collection tool, and structured interviews to measure adherence. Morisky Medication Adherence Scale- 8 items (MMAS) and the four-item Morisky Green Levine Medication Adherence Scale (MGLS) self-report measure was the most common measures used for evaluating medication adherence, which was applied in 5 $(23.8 \%),{ }^{22,23,46,47,51}$ and $4(19 \%)$ studies,$^{52,53,55,56}$ respectively.

Nine studies used the electronic data records (pharmacy or medical claims database) to measure medication adherence, which different measures were utilized, including the percentage of days covered (PDC), medicine possession ratio (MPR), prescription fill, and missing days. The PDC is the number of days a patient gets each medication divided by the number of days for eligibility for medication, greater than $80 \%$ mean patient have adequate adherence, which $80 \%$ considered cut-off between adherent and nonadherent patients as used by LeBlanc et al. ${ }^{68}$ Also, the MPR is the number of days that doses were dispersed divided by the total number of days between the first and last doses. It is dichotomized into greater than $80 \%$ considered adherent and lower than or equal $80 \%$ considered nonadherent as used by Holvast et al ${ }^{66}$, and Slabbert et $\mathrm{al}^{69}$ reported that patients considered adherence if MPR was between [?] $80 \%$ and [?] $110 \%$.

Regarding prescription fill and missing days, nonadherence described if medication discontinued before 180 days after the index refill date. ${ }^{63}$ Other studies defined adherence as the proportion of compliance during the first 24 weeks from prescription fill. ${ }^{67}$ Also, Yau et $\mathrm{al}^{25}$ measured adherence as filled prescriptions for medications with no gaps of more than 15 days within six months after the start of treatment. On the other hand, two studies used pill count by calculating the actual number of pills taken dividing by the expected number of pills taken during the study period and multiplying by $100 \cdot{ }^{71}$ Other study was calculated by the total number of weeks the participants took medication. ${ }^{72}$

\section{Factors Affect to Medication Adherence}

Several factors have been shown that hinder patients from taking their medication as prescribed. World Health Organization (WHO) has categorized common factors that affect adherence to five different dimensions. ${ }^{3}$ The five dimensions of adherence are socioeconomic, healthcare provider/system, illness, medication, and patient-related factors. ${ }^{3}$ As described below, these five dimensions used in this scoping review to extract the factors from included studies. Factors that could contribute to medication adherence among patients diagnosed with MDD are summarized and presented in Table 5. However, studies are not consistent about the relationship between factors and adherence. Over 33 included studies, 26 of them investigated the factors that influence medication adherence. The following section will explore commonly reported reasons and factors associated with adherence to medications.

Socioeconomic related factors. Language and literacy have been associated with the adherence level. ${ }^{64}$ By using different self-reported assessment methods, medication adherence was related significantly to income ${ }^{56,57}$ level of education. ${ }^{52,57}$ Regarding living conditions, Yau et al ${ }^{25}$ noted that the type of accommodation associated with noncontinuous use of AD medications. Patients whose accommodation in public housing property that reflects low socioeconomic status was related to noncontinuous use of AD medications. ${ }^{25}$ On the other hand, the occupation of patients has a relationship with an adherence level of medication. Also, patient occupation in service and farming reported a significantly high adherence rate than business, housewife, and students. ${ }^{60}$

Lack of family support and the nature of the job stated the reasons for nonadherence. ${ }^{57,65}$ Studies conducted in different contexts reported that lack of support from family members, spouses, and friends was found barriers from delayed initiating $\mathrm{AD}$ medication and continuing it. ${ }^{24,73}$ Also, Ho et al ${ }^{24}$ and Vargas et al ${ }^{74}$ 
noted that social-cultural stigma influences on adherence, which stigmatizing views held by others in patients' social circle were depression is a sign of madness and negative personal characteristics. Moreover, religion and cultural beliefs have been barriers to medication adherence. ${ }^{24}$

Healthcare provider/System-related factors. Accessibility to healthcare services included longdistance, poor access to healthcare locations, long waiting time at the clinic, limited time with psychiatric doctor, and lack of accessible appropriate material influence to medication adherence. Compared to the short distance, patients who move to the psychiatric clinic from long-distance five times nonadherent to medications. ${ }^{22}$ Ho et $\mathrm{al}^{24}$ reported that patients who have experienced long waiting times at the clinic and lack of transportation to healthcare locations hospital resulted in patients not taking medications. Also, poor of access to different formats of informational materials in psychiatric clinic influence on medication adherence, which included lack of verbal and written instructions and information, use different language in instructions and information, and use appropriate format for patient with physical disability (e.g., hearing and visual impairment). ${ }^{64}$ Furthermore, the limited time of follow-up visits with the psychiatrist in the clinic affects adherence to medication. ${ }^{64}$

The change of psychiatrists and multiple prescribers every visit affects the patient's confidence and trust toward providers, which later affected their medication-taking behavior, ${ }^{24}$ and non-availability of psychiatrists during follow-up one of the reasons for nonadherence. ${ }^{57}$ In addition, the satisfaction level of the patient with psychiatrists is related to adherence. ${ }^{21}$ On the other hand, the frequency of follow-up visits to psychiatric clinic affects adherence to medications. ${ }^{21,24,34}$ The lower number of visits to clinics related significantly to a low level of adherence to $\mathrm{AD}$ medications. ${ }^{23,25}$

Ho et $\mathrm{al}^{24}$ presented the poor communication between the patient and provider could impede medication adherence. In addition, inadequate information on medications and disorders, and healthcare provider guidance related to the low level of adherence (Srimongkon et al. 2018). ${ }^{57,64}$ In spite of appropriate information and guidance, access to medication in facilities are still relating to continuous taking medications. ${ }^{24,57,73}$

Illness-related factors. Acute onset of the illness associated with the early withdrawal was experienced in the patients with MDD. ${ }^{65}$ Also, earlier MDD diagnostics minimize the non-continuous behaviors of AD medication. ${ }^{25}$ For the duration of illness, a short duration of illness significant in relation to high rates of adherence. ${ }^{23}$ Alekhya et $\mathrm{al}^{21}$ noted the correlation between low adherent patients with patients experienced more than a year of illness. In the same way, the risk of nonadherence to medication in patients who have been diagnosed MDD for more than two years is high. ${ }^{22}$ Furthermore, the adherence to medication is influenced by symptoms and the severity of the disease. Lucca et $\mathrm{al}^{57}$ demonstrated that patients reported forgetfulness, no improvement, and deterioration of conditions impaired the adherence to medication. A phenomenological study reveals that depressive symptoms; forgetfulness, lethargy, and laziness impair the adherence of AD medications. ${ }^{73}$ Similarly, other studies have shown that somatic symptoms associated with an early dropout of treatment. ${ }^{65}$ Furthermore, nonadherent patients are closely associated with high physical pain. ${ }^{48}$ De las Cuevas et $\mathrm{al}^{52}$ have found that patients with a severe degree of depression related to nonadherent patients. However, the opposite association between adherence and depression severity, which clarified that lower depressiveness was significantly correlated with higher medication adherence rates. ${ }^{23,48}$ In another study, the research in Beijing has revealed that few episodes of preceding depression had a significant impact on medication adherence that had a positive relationship to increased medication adherence. ${ }^{56}$ The number of psychiatric hospitalizations influence factors to medication adherence. A more significant number of psychiatric hospitalizations correlated with a high degree of non-compliance medications have been reported by Baeza-Velasco et al ${ }^{48}$ In addition, in co-morbid illnesses, included studies have reported that patients with MDD who comorbid with physical illnesses, alcohol dependence and illicit drug, and concomitant psychiatric illness negatively interfered with adherence to AD medications. ${ }^{21,22,24,65,48}$

Conversely, patients with co-morbid anxiety exhibited high adherence to medications. ${ }^{56}$ Patients with a family history of depression and past history of depression were also strongly in nonadherence. ${ }^{21}$ Also, in patients with a suicidal ideation and attempts, a poor adherence level is also substantially increased. ${ }^{21,48}$ Indeed, a cross-sectional study was performed of patients with bipolar disorder, schizophrenia, schizoaffective, 
depression, and other psychiatric disorders at the psychiatric clinic, which showed that the diagnosis had a major effect on nonadherence to medications. ${ }^{34}$

Medication-related factors. According to recent studies, complex treatment regimens impair adherence significantly. Alekhya and colleagues ${ }^{21}$ found out that polypharmacy has a major impact on adherence; the most significant number patients are not adhering to a multiple drug system. Also, patients with co-morbidities discontinue AD medications related to the barrier of pill burden, which they are taking so many types of medications. ${ }^{24}$ In addition, statistically significant is the relationship between the number of prescription medications and medication adherence. ${ }^{49,57}$ Moreover, previous studies stated that adverse reactions have association with level of medication adherence. ${ }^{21,25,49,62,64,65,73}$ In addition, nonadherence is related to severity and the amount of adverse effects. ${ }^{52}$ Ho et $\mathrm{al}^{24}$ reported that patients have stopped taking medications associated with the experience of side effects. Other included studies have found that patients with MDD describe and stated that the majority of reasons for nonadherence are an adverse reaction. ${ }^{34,57,60}$

The duration of treatment can also affect adherence to medications. Findings by using MPR reported that statistically and practically important the duration of treatment is correlated with adherence to medication. ${ }^{69}$ Lucca et $\mathrm{al}^{57}$ noted that during the first three months of treatment patients continue to take medication with a significant association with medication nonadherence. The qualitative study concluded that patients who are concerned about the long-term effects of $\mathrm{AD}$ medications have a negative effect on the implementation of therapy. ${ }^{73}$ Inconvenient dose regimen may affect medication adherence, which explained that doses could be needed once a day, twice a day, three times a day or more than four times a day. ${ }^{73}$ In other studies, the cost of medication was a factor for nonadherence, ${ }^{57}$ and is correlated substantially with nonadherence. ${ }^{60}$ Studies that have assessed adherence to the prescribed class of medication reported that the type of active ingredients consumed or formulations and adherence were significantly related. ${ }^{57,69}$ However, the most common reason for discontinuance was the ineffective response of the medication. ${ }^{58}$

Patient-related factors. Patient factors associated with medications adherence represent sociodemographic factors (age, gender, race, marital status), psychological factors (beliefs, attitudes, satisfaction, knowledge, psychological reactance, locus of control, self-stigma, self-motivation, insight, self-management), and physical (cognitive and behavioral) factors (forgetfulness, the patient's personal obligation, carelessness, confusion).

Age considered the predictor of adherence to prescribed medications, in Spain, adherence to AD medication was assessed in the two community mental health centers located on Tenerife Island, and the result was that the likelihood of adherence to the medication for older patients was lower. ${ }^{53} \mathrm{~A}$ study that has compared the level of adherence reported lower adherence levels for patients older than 60 years than for patients aged 18-40 years. ${ }^{69}$ In contrast, Al-Jumah et $\mathrm{al}^{23}$, found that older patients had a high level of adherence. In addition, young age patients significantly associated with noncontinuous use of AD medication. ${ }^{25}$

Gender is an important factor in the non-continuing use of AD medications, with female patients showing a high level of non-continuous use of AD medications. ${ }^{25}$ In addition, the energetic disparity of the male is a statistically important differentiation for adherence. ${ }^{23}$ However, race-gender also associations with adherence, $\mathrm{AD}$ adherence difference across four race-gender subgroups (African-American women, African-American men, White women, and White men), white women more likely to be adherent to their AD medication 3.1 times than African-American women. ${ }^{50}$ Moreover, marital status exhibits significant differences in the level of medication adherence. According to Baeza-Velasco et $\mathrm{al}^{48}$ reported that high adherent patients have a partner.

A patient's beliefs are influence decisions of medication-taking behavior, the necessity beliefs of medications associate positively with adherence to medication; likewise, the beliefs of concern, harmfulness, and overuse related with nonadherence to medication. ${ }^{23,49,51,62}$ The beliefs that psychiatric medications general harmfulness is in relation to nonadherent patients. ${ }^{52}$ Nonadherent patients displayed a high degree of concern for medications perceived to have potential adverse effects, such as dependence, side-effects, or accumulation effects. ${ }^{52}$ In another study, the belief that the medication relieves the symptoms, does not relieve the symp- 
toms, increases the severity of the disease, and the belief that they do not suffer from a psychiatric illness; these reasons impressed continuous of treatment. ${ }^{65}$ In addition, patients have reported necessity beliefs such as $\mathrm{AD}$ that help treat depression, safe for most patients; it must be taken daily for several weeks to ensure it works, which positively affects their adherence. ${ }^{64}$ Also, harm beliefs that explained that medications are addictive associated with a low level of adherence. ${ }^{64}$ Other study presented that patients showed incorrect beliefs about MDD and AD medications, and harm beliefs of fear of medication dependence that related to adherence. $^{24}$

Indeed, high necessity beliefs significant predictors of high AD medication adherence which explained through patients' beliefs that AD medication could protect against exacerbation of depression; without AD medication, they will be very depressed; the mental health status will depend on AD medication. ${ }^{56}$ Also, negative impact between the concern beliefs about the $\mathrm{AD}$ medications and $\mathrm{AD}$ medication adherence expressed through concern about their long-term consequences, heavily depends on them, they are a mystery, they disturb life. ${ }^{56}$ Srimongkon et $\mathrm{al}^{73}$ reported that the patients' beliefs that medication efficacy has a positive influence on adherence and negative factors on adherence in patients with concern regarding therapeutic effects and side effects of medications. Qualitative interviews of the experiences of Latino outpatients with MDD investigated depression and pharmacotherapy perspectives, concluded that patients had concerns regarding medications and depression that may have been perceived as obstacles to treatment and medication adherence. $^{74}$

Concern beliefs over the fear of dependence on AD medications, physical ramifications for taking AD medications, risk of deteriorating depression and mental health, high dosages of prescription are hazardous, irrepressible adverse effects, and alternative cures have less antagonistic impacts than AD medications. ${ }^{74}$ Also, concern beliefs about depression referred that depression is exacerbated and not relive. ${ }^{74}$ Other barriers are beliefs about AD medications use that disagreement with psychiatric advice, which patients believe that it is the last choice, it is should work immediately, it is used when feeling depressed and take high doses of it, and not take when feeling better. ${ }^{74}$ In addition, the fear about the medications and from addiction are barriers to medication adherence. ${ }^{57,74}$

On the attitude towards medication, there is a positive attitude related to adherent patients, ${ }^{48,52,64}$ and vice versa. ${ }^{24}$ According to statistical differences between adherent and nonadherent patients, adherent patients show a stronger positive attitude than nonadherent patients. ${ }^{59}$ In addition, low-level adherence to AD medication is associated with low treatment satisfaction ${ }^{23}$, lack of knowledge. ${ }^{24}$ On the other hand, adherence to medications can be influenced by a negative emotional reaction to regulations or recommendations of medication use that affect freedom and autonomy, and beliefs regarding the control of health. Psychological reactance and chance external locus of control have positive associations and levels of adherence, where more reactant patients are less adherent, also a negative relationship with an external locus of control, where more adherence when patients depend on their doctors. ${ }^{53}$

Patients who take AD medications seen is a sign of not normal and effect on behavior and mental state, so this self-stigma towards AD medications affect medication adherence. ${ }^{74}$ Also, self-stigma over depression, denial about their disorder, nonacceptance of the disorder considered the major reason for noncontinuous $\mathrm{AD}$ medication..$^{25,34,73} \mathrm{On}$ the other hand, the expression of patients that want to feel better and experience severe depressive symptoms that motivate adherence to AD medications. Srimongkon et $\mathrm{al}^{73}$ reported that patients revealed that self-motivation and self-management have a positive impact on adherence. Although, the insight of diagnosis may factor that influence adherence. ${ }^{24,57}$ Moreover, patients revealed that forgetfulness is a negative effect on medication adherence. ${ }^{24,60}$ The patient's personal obligations such as traveling; carelessness; and confusion negatively influence $\mathrm{AD}$ medication adherence. ${ }^{57,60}$

\section{Interventions Strategies for Improving Medication Adherence}

Ten of the 36 included studies have evaluated the effectiveness of various interventions to improve medication adherence among patients diagnosed with MDD as presented in Table 6. Since adherence was related to health outcomes, medication adherence enhancing interventions should design and implement that can 
reflect in increase the number of patients who adhere to medication. These have ranged from single element interventions and through to multi-element intervention packages. These interventions have been categorized into counseling (cognitive, behavioral interventions), education and information, reminders, monitor feedback (adherence and disease), and multi-faceted intervention. Multi-faceted interventions defined as intervention including two or more components such as education with monitor feedback, and cognitive education with counselling. ${ }^{75}$ Out of 10 studies, five randomized controlled studies, one cluster randomized trial study, one randomized controlled trial with two parallel-group posttest-only study, one pre-post onegroup intervention study, one observational retrospective cohort study, and one prospective nonrandomized open-label naturalistic observational study.

In two studies the intervention was delivered as integrated service in primary health centers by pharmacists and pharmacy students to examine intervention, ${ }^{49,67}$ other study was delivered enhanced care home visits in primary health centers after the first medical consultation by community health workers. ${ }^{72}$ Hammonds et $\mathrm{al}^{71}$ used electronic medication reminder application through a smartphone device to enhance adherence to $\mathrm{AD}$ medications and evaluated after about 35 days from the initial assessment. Also, bibliotherapy and text messaging a novel approach delivered as counseling (cognitive, behavioral interventions) developed by psychologists, psychiatrists, and community medicine specialists. ${ }^{61}$ Five studies were provided the intervention from 1 to 4 sessions to patients by pharmacists, psychiatrist, physicians, social workers, nurses, and candidate master degree researcher. ${ }^{19,47,54,62,68}$

Interventions Based on Monitored Adherence Feedback. The use of pharmacy management service and community healthcare service has been shown to have positive effects on medication adherence. ${ }^{49,67}$ Pharmacist-led multidisciplinary AD telemonitoring service provided monitoring of patients for early interventions following $\mathrm{AD}$ initiation or up-titration to enhance adherence, relieve adverse effects, and minimize suicide risks through education and information and monitor feedback (adherence and disease). ${ }^{49}$ Also, community pharmacists (CPs) management which used education and information, reminders, and monitor feedback (adherence and disease) approach, compared CP management with treatment-as-usual (TAU) after 1 and 6 -months $\mathrm{AD}$ treatment adherence rate was high among patients received $\mathrm{CP}$ management. ${ }^{67}$ Other study was delivered enhanced care home visits as education and information and monitor feedback (adherence and disease) in primary health centers after the first medical consultation by community health workers. The enhanced care home visits group as a treatment intervention (TI) showed a significant completed the treatment and treatment adherence compared with the treatment as usual (TAU) group. However, there was no significant difference in the outcomes of depression at six months follow up. ${ }^{72}$

Interventions Based on Reminder Systems. Use of electronic medication reminder application increase adherence to AD medications. ${ }^{71}$ Electronic medication reminder application via smartphone for about 35 days in a randomized, parallel-group clinical trial enhance adherence to AD medications in college students. ${ }^{71}$

Education and Information Interventions. The use of information in a different form of delivery, verbal, written, or audiovisual. These interventions are designed to educate patients to promote medication adherence and motivate patients by sufficiently describing the way of taking medication, producing and discussing with patients any reluctance to take medication, and discussing with patients their beliefs and knowledge about their condition and treatments. ${ }^{47,68}$ This intervention focuses on patients, context, and health care system, which adopting patient-centered care and sharing decision-making principles ${ }^{47,68}$ Providing information about $\mathrm{AD}$ medications by pharmacist interventions, it significantly improves medication adherence, treatment satisfaction, general overuse beliefs, and specific concern beliefs. However, the severity of depression and health-related quality of life did not make a difference between the interventional and control group after six months. ${ }^{47}$ However, other studies used depression medication choice as a novel shared decisionmaking approach, compared with usual care found that no difference in medication adherence, depression control, or encounter duration. ${ }^{68}$

Cognitive-Behavioral Counseling Interventions.Cognitive-behavioral therapy (CBT), as a new discovery, which is being applied in the field of psychotherapy, has proven effective in improvements in selfconcept, pessimistic worldview, negative thoughts, and medication adherence. ${ }^{32}$ The use of a novel approach 
of cognitive-behavioral interventions through bibliotherapy (booklet) and text messaging by allocated to three groups, control, booklet, and booklet and text messaging. The data collected three times: before the intervention, immediately after intervention, and three months after intervention. Medication adherence insignificant within each group at different times, while it was statistically significant in the interactive effect of group factor and the time factor. ${ }^{61}$

Multi-Faceted Intervention. A single element approach has limited effectiveness on medication adherence because the factors determining adherence interact and potentiate each other's influence. ${ }^{3,32}$ On the other hand, adequate evidence has been supporting that multi-faceted most effective approach, which targets more than one factor by more than one strategy. Several programmers have demonstrated effective outcomes using a multi-elements approach. ${ }^{19,54,62}$ Examples include the treatment initiation and participation program (TIP), drug adherence enhancement program, and psychoeducation with basic CBT strategies. ${ }^{19,54,62}$ Particularly, multi-elements approach significantly improvements in the knowledge of depression, attitude towards medication adherence, and reductions in depressive symptoms compared with TAU. ${ }^{19,54,62}$

Furthermore, the use of pharmacy management service and community healthcare service as a multi-faceted approach has been shown to have positive effects on medication adherence. ${ }^{49,67,72}$ Pharmacist-led multidisciplinary AD telemonitoring service provided monitoring of patients for early interventions following $\mathrm{AD}$ initiation or up-titration to enhance adherence, relieve adverse effects, and minimize suicide risks through education and information and monitor feedback (adherence and disease). ${ }^{49}$ Also, community pharmacists (CPs) management which used education and information, reminders, and monitor feedback (adherence and disease) approach, compared CP management with treatment-as-usual (TAU) after 1- and 6-months AD treatment adherence rate was high among patients received CP management. ${ }^{67}$ Other study was delivered enhanced care home visits as education and information and monitor feedback (adherence and disease) in primary health centers after the first medical consultation by community health workers. The enhanced care home visits group as a treatment intervention (TI) showed a significant completed the treatment and treatment adherence compared with the treatment as usual (TAU) group. However, there was no significant difference in the outcomes of depression at six months follow up. ${ }^{72}$

\section{Discussion}

As described at the beginning in this scoping review, medication nonadherence is a problem affects the health care system, healthcare professionals, and patients. So, to the best of our knowledge, this is the first scoping review that summarize and identify medication adherence rate, types of measurement methods, factors of nonadherence to medication, and types of medication adherence enhancing interventions among patients with MDD. Our findings provided many insights into the importance to focus on the prevalence of adherence, factors affect to adherence, and interventions to improve adherence in patients with MDD. Also, attention and expand the body of knowledge towards medication adherence in MDD facilitates healthcare organizations, policymakers, professions, and researcher in the design and implementation of medication adherence enhancing strategies.

This scoping review included 36 in the past 5 years met our eligibility criteria, selected by using selection process of PRISMA-ScR guidelines. ${ }^{42}$ The authors attempted to adjust the need to lessen the heterogeneity of selected studies for the one hand while assuring the fitting impression of valid practice on the other. Consequently, the main results divided according to the research questions. In the identified articles, the current authors noted that the quality of the most included studies was generally good, except for one study by Shrestha Manandhar et al ${ }^{60}$ which yielded the lowest score $(25 \%)$ using MMAT. The authors identified the prevalence of medication adherence are range from $10.6 \%$ to $85.4 \%$, and the rate of medication adherence in majority of studies are low $(<60 \%) .{ }^{21-23,25,46,48,52,53,55,56-58,60,63-71}$

Concerning the variation of adherence rate, the current authors were unable to standardize the adherence rates related to the variation in study designs, adherence measures, and inconsistent definitions of medication adherence were associated with unacceptable heterogeneity. Regarding the adherence measures, researchers used various methods in an attempt to assess patient adherence to medication, but none of them can be 
considered universally accepted "gold Standard" for measuring adherence. The majority of studies in this scoping review used indirect measures such as self-reported questionnaires and pharmacy refill data. This is because direct methods such as biological measures are not always acceptable, appropriate, feasible, or cost-effective. ${ }^{18}$ This view potentially explains that most studies (22) measuring adherence based on selfreport as subjective measurements, there were 12 different measures. Also, nine studies used objective measurements by using the electronic data records and two studies used pill count. Although, views as to the best measurements vary, each is acknowledged to have its advantages and limitations. The advantages of indirect measures in these studies are flexible, easy to administer, relative unobtrusiveness, inexpensive, and time-saving to complete. However, limitations may be subject to bias (e.g., refill prescription is different to ingestion of medication), social desirability, and overestimate adherence. ${ }^{19,25,47,53-55,57,58,69,70,72}$

However, 26 of included studies investigated the factors that influence medication adherence among patients with MDD. This scoping review identifies multi-factorial causes leading to poor medication adherence, which classified as WHO into five categories: socioeconomic, healthcare provider/system, illness, medication, and patient-related factors. ${ }^{3}$ This scoping review recognizes illness, medication, and patient-related factors were the most factors associated with medication adherence. This explained that the common factors to adherence are under the patient's control, which patient's perspective toward illness and medication maybe is a considered decision by patients making their own choices about taking medications, based on their beliefs, personal conditions, and the information offered to them.

However, various interventions address the aforementioned factors to improve adherence. With an understanding of the factors that influence medication adherence among patients with MDD, proper intervention can then be tailored individually to improve the medication-taking behavior of each patient. Our scoping review identified ten studies that used a range of counseling, education and information, reminders, monitor feedback, and multi-faceted intervention to improve medication adherence among patients with MDD. These interventions implemented by many different health care workers who have an essential role in improving adherence because they can influence one or more of the factors that determine adherence.

The number of studies with either positive or no effects. The most common interventions targeting healthcare provider/system and patient-related factors were evident such as Aljumah \& Hassali ${ }^{47}$, Isa et $\mathrm{al}^{54}$, Sirey et $\mathrm{al}^{19}$, Taleban et $\mathrm{al}^{61}$, and Vannachavee et $\mathrm{al}^{62}$. The present review showed that a single-element intervention might be expected to have been less effective on medication adherence. ${ }^{47,61,68,71}$ However, there is no universal intervention that is suitable for all nonadherent patients. In this scoping review, multi-faceted intervention is most interventions used in 6 included studies. In addition, the six studies presented a significant result about improving medication adherence. Nieuwlaat et $\mathrm{al}^{32}$ noted that effective intervention is complex, involves several components to address a multi-factorial approach that effect on medication adherence.

However, healthcare professionals play an essential role in assessing patients with nonadherence and delivering appropriate interventions to support and improve adherence, persistence, and retention in medication and care. Also, nurses play a key role in screening, assessing, and promoting medication adherence.

\section{Limitations}

The following limitations should be mentioned for this study. First, the search was limited to the last five years and English language publications. Second, this is not a comprehensive review of all the existent medication adherence measures and interventions. However, it focused on the different types available and the most commonly used among patients with MDD.

\section{Conclusion}

The results of this scoping review highlight that nonadherence to the medication among patients with MDD is a major obstacle in reducing public health challenges in both developed and developing countries. The evidence shows that patients with MDD have a high rate of medication nonadherence. However, accurate assessments of medication adherence will provide better evidence on the outcomes, risk factors, and interventions to improve medication adherence. Numerous measurements available for assessments of 
medication adherence, also need to prove to be valid, reliable, and sensitive. However, the selection of measurements should be based on researcher or healthcare professionals' attributes, goals, resources of the clinical setting, or study. Although, none of the measurements can be considered as a gold standard, and the triangulation of measures is recommended. The behaviors of taking mediation are often faced multi-factorial causes, identify of it important to implement appropriate medication adherence enhancing interventions. Also, interventions require several components to focus on these factors, and health care professionals must follow a systematic process to assess possible factors.

\section{Implication}

The findings of this scoping review presented important implications for practice, administration, policy, education, and future research. For practice, healthcare professionals need to integrate assessments of level, reasons, and factors that influence medication nonadherence into practice. They need to improving medication adherence and understanding factors that influence nonadherence behavior can enable healthcare professionals to identify interventions and improve the patient's adherence behaviors and long-term health outcomes. Moreover, they should aim to maintain medication adherence through involvement healthcare professionals in providing medication adherence enhancing interventions to improve patients' beliefs and behaviors, as well as use multi-faceted intervention and ongoing follow-up, which may assist patients in achieving greater long-term adherence to medication. Although should providing training for healthcare professionals on assessments of level, factors that influence medication nonadherence, communication skills, and provide continuous monitoring for patients. In addition, this scoping review confirms to formalization and integration of the adherence assessment process into routine practice and highlights the importance of multidisciplinary support required for a successful assessment of medication-taking behavior.

For administration, this could be achieved by integrating and designing appropriate assessment measures and interventions regarding MDD and medication adherence. For policy, it should emphasize a collaborative effort of researchers, healthcare professionals, and stakeholders to improve medication adherence. Also, emphasize integrate statistics of medication adherence into the healthcare databases. This highlights to focus on and increase the number of medication adherence enhancing interventions that are supported by health care institutions. Also, develop a guideline for medication adherence measures, medication adherence enhancing interventions, and follow-up strategies.

For education, nursing students should be aware of the concept of adherence, the outcome of nonadherence, and the interventions of adherence. Particularly, measures, influencing factors, and types of medication adherence enhancing interventions should be taught in nursing programs. In addition, health nursing care plans may need to include medication adherence and self-monitoring assessment to be standard for students clinical practice. Therefore, nursing programs should focus on teaching students how to assess medication adherence.

The current scoping review could be extended and improved upon in several areas. For future research, we need research on nonadherence to medication among patients with MDD as well as interventions to promote patients' adherence to treatment, as most of the research that was identified was recommended only in specific settings, diseases, treatments, and it included small samples of the study. The researchers could utilize rigorous methodological approaches and focus on investigating clinical features and factors that could influence medication adherence among patients with MDD. In addition, the researchers could utilize objective measures of adherence, and triangulation of methods is recommended that could give more naturalistic and precise findings. Future research can also explore and develop additional and new interventions to address factors that could influence medication adherence as well as the effectiveness of current efforts to enhancement adherence to medication among patients with MDD.

\section{Authorship}

The authors participated in the process of systematic retrieval, evaluation, analysis of studies, results, and manuscript preparation; details of each contribution are presented in the method section. Results and manuscript preparation. 


\section{Acknowledgements}

The authors thank The University of Jordan-School of Nursing for library facilitation and assistance.

\section{Funding}

None

\section{References}

1. Lehane E, McCarthy G. Intentional and unintentional medication non-adherence: A comprehensive framework for clinical research and practice? A discussion paper. Int J Nurs Stud . 2007;44(8):14681477. doi:10.1016/j.ijnurstu.2006.07.010

2. Vrijens B, De Geest S, Hughes D et al. A new taxonomy for describing and defining adherence to medications. Br J Clin Pharmacol . 2012;73(5):691-705. doi:10.1111/j.1365-2125.2012.04167.x

3. Sabate E. Adherence To Long-Term Therapies: Evidence For Action . Geneva: World health organization; 2003.

4. Brown M, Bussell J, Dutta S, Davis K, Strong S, Mathew S. Medication Adherence: Truth and Consequences. Am J Med Sci . 2016;351(4):387-399. doi:10.1016/j.amjms.2016.01.010

1. Jafari Oori M, Mohammadi F, Norouzi-Tabrizi K, Fallahi-Khoshknab M, Ebadi A. Prevalence of medication adherence in patients with hypertension in Iran: A systematic review and meta-analysis of studies published in 2000-2018. ARYA Atheroscler . 2019;15(2):82-92. doi:10.22122/arya.v15i2.1807

2. Cheen M, Tan Y, Oh L, Wee H, Thumboo J. Prevalence of and factors associated with primary medication non-adherence in chronic disease: A systematic review and meta-analysis. Int J Clin Pract. 2019;73(6):e13350. doi:10.1111/ijcp.13350

3. Mongkhon P, Kongkaew C. Medication Non-Adherence Identified at Home: A Systematic Review and Meta-analysis. Qual Prim Care . 2017;25(2):73-80.

4. Uchmanowicz B, Jankowska E, Uchmanowicz I, Morisky D. Self-Reported Medication Adherence Measured With Morisky Medication Adherence Scales and Its Determinants in Hypertensive Patients Aged [?]60 Years: A Systematic Review and Meta-Analysis. Front Pharmacol . 2019;10. doi:10.3389/fphar.2019.00168

5. Gebeyehu D, Mulat H, Bekana L et al. Psychotropic medication non-adherence among patients with severe mental disorder attending at Bahir Dar Felege Hiwote Referral hospital, north west Ethiopia, 2017. BMC Res Notes . 2019;12(1). doi:10.1186/s13104-019-4126-2

6. World Health Organization (WHO). Mental disorders. Who.int. https://www.who.int/newsroom/fact-sheets/detail/mental-disorders. Published 2018. Accessed November 13, 2019.

7. Greenberg P, Fournier A, Sisitsky T, Pike C, Kessler R. The Economic Burden of Adults With Major Depressive Disorder in the United States (2005 and 2010). J Clin Psychiatry . 2015;76(02):155-162. doi:10.4088/jcp.14m09298

8. American Psychiatric Association (APA). Diagnostic And Statistical Manual Of Mental Disorders (DSM-5@) . 5th ed. Washington, D.C.: American Psychiatric Association; 2013.

9. Bromet E, Andrade L, Hwang I et al. Cross-national epidemiology of DSM-IV major depressive episode. BMC Med . 2011;9(1). doi:10.1186/1741-7015-9-90

10. Ferrari A, Charlson F, Norman R et al. Burden of Depressive Disorders by Country, Sex, Age, and Year: Findings from the Global Burden of Disease Study 2010. PLoS Med . 2013;10(11):e1001547. doi:10.1371/journal.pmed.1001547

11. World Federation for Mental Health. DEPRESSION: A Global Crisis . Who.int: World Health Organization; 2012. https://www.who.int/mental_health/management/depression/wfmh_paper_depression_wmhd_2012.pdf. Accessed November 20, 2019.

12. Ho S, Chong H, Chaiyakunapruk N, Tangiisuran B, Jacob S. Clinical and economic impact of nonadherence to antidepressants in major depressive disorder: A systematic review. J Affect Disord . 2016;193:1-10. doi:10.1016/j.jad.2015.12.029

13. Brijnath B, Antoniades J. "I'm running my depression:" Self-management of depression in neoliberal 
Australia. Soc Sci Med . 2016;152:1-8. doi:10.1016/j.socscimed.2016.01.022

14. Lam W, Fresco P. Medication Adherence Measures: An Overview. Biomed Res Int . 2015;2015:1-12. doi:10.1155/2015/217047

15. Sirey J, Banerjee S, Marino P et al. Adherence to Depression Treatment in Primary Care. JAMA Psychiatry . 2017;74(11):1129. doi:10.1001/jamapsychiatry.2017.3047

16. Sriharsha M A. Treatment and Disease Related Factors Affecting Non-adherence among Patients on Long Term Therapy of Antidepressants. Journal of Depression and Anxiety . 2015;04(02). doi:10.4172/2167-1044.1000175

17. Alekhya P, Sriharsha M, Priya Darsini T et al. Treatment and Disease Related Factors Affecting Non-adherence among Patients on Long Term Therapy of Antidepressants. Journal of Depression and Anxiety . 2015;04(02). doi:10.4172/2167-1044.1000175

18. Abegaz T, Sori L, Toleha H. Self-Reported Adverse Drug Reactions, Medication Adherence, and Clinical Outcomes among Major Depressive Disorder Patients in Ethiopia: A Prospective Hospital Based Study. Psychiatry J . 2017;2017:1-8. doi:10.1155/2017/5812817

19. Al-Jumah K, Ahmad Hassali A, El Tahir K, Al Qhatani D. Factors associated with adherence to medication among depressed patients from Saudi Arabia: a cross-sectional study. Neuropsychiatr Dis Treat . 2014:2031. doi:10.2147/ndt.s71697

20. Ho S, Jacob S, Tangiisuran B. Barriers and facilitators of adherence to antidepressants among outpatients with major depressive disorder: A qualitative study. PLoS ONE . 2017;12(6):e0179290. doi:10.1371/journal.pone.0179290

21. Yau W, Chan M, Wing Y et al. Noncontinuous use of antidepressant in adults with major depressive disorders - a retrospective cohort study. Brain Behav . 2014;4(3):390-397. doi:10.1002/brb3.224

22. Michel M. Adherence and Treatment Outcomes among Patients with Comorbidity of Depression and Other Mental Disorders attending Psychiatric Hospitals in Rwanda. 2014.

23. World Health Organization (WHO). Depression and other common mental disorders: global health estimates. World Health Organization. https://www.who.int/mental_health/management/depression/prevalence_global_health_estimates/en/. Published 2017. Accessed November 13, 2019.

24. Chong W, Aslani P, Chen T. Effectiveness of interventions to improve antidepressant medication adherence: a systematic review. Int J Clin Pract . 2011;65(9):954-975. doi:10.1111/j.1742-1241.2011.02746.x

25. Gratacos Torras M, Pousa Tomas E. INTERVENCIONES PARA MEJORAR LA ADHERENCIA TERAPEUTICA EN SUJETOS CON ESQUIZOFRENIA. Papeles del Psicologo - Psychologist Papers . 2018;39(1). doi:10.23923/pap.psicol2018.2850

26. Ehret M, Wang M. How to increase medication adherence: What works?. Mental Health Clinician . 2013;2(8):230-232. doi:10.9740/mhc.n132973

27. Haddad P, Brain C, Scott J. Nonadherence with antipsychotic medication in schizophrenia: challenges and management strategies. Patient Relat Outcome Meas . 2014:43. doi:10.2147/prom.s42735

28. Nieuwlaat R, Wilczynski N, Navarro $T$ et al. Interventions for enhancing medication adherence. Cochrane Database of Systematic Reviews . 2014. doi:10.1002/14651858.cd000011.pub4

29. Cameron C, Habert J, Anand L, Furtado M. Optimizing the management of depression: primary care experience. Psychiatry Res . 2014;220:S45-S57. doi:10.1016/s0165-1781(14)70005-8

30. Mert D, Turgut N, Kelleci M, Semiz M. Perspectives on reasons of medication nonadherence in psychiatric patients. Patient Prefer Adherence . 2015:87. doi:10.2147/ppa.s75013

31. Farooq S, Naeem F. Tackling nonadherence in psychiatric disorders: current opinion. Neuropsychiatr Dis Treat . 2014:1069. doi:10.2147/ndt.s40777

32. Olfson M. Bringing Antidepressant Self-Discontinuation Into View. Psychiatric Services . 2015;66(5):449-449. doi:10.1176/appi.ps.660501

33. Kleppe M. Understanding medication adherence: a self-report measure and a dual-process framework. 2016.

34. Stein-Shvachman I. Depression Treatment Non-adherence and its Psychosocial Predictors: Differences between Young and Older Adults?. Aging Dis . 2013;4(6):329-336. doi:10.14336/ad.2013.0400329 
35. Fiaturi N, Greenblatt D. Therapeutic Drug Monitoring of Antidepressants. Antidepressants . 2018:115133. doi:10.1007/164_2018_161

36. Okasha A, Alkhadhari S, Al Sharqi A. Arab Treatment Guidelines for the Management of Major Depressive Disorder $=$ dlyl l'lj l'rby fy tdbyr DTrb lkty'b ljsym. The Arab Journal of Psychiatry . 2017;28(2):97-117. doi:10.12816/0041709

37. Párraga Martínez I, López-Torres Hidalgo J, del Campo del Campo J, Villena Ferrer A, Morena Rayo S, Escobar Rabadán F. Seguimiento de la adherencia al tratamiento antidepresivo en pacientes que inician su consumo. Atención Primaria . 2014;46(7):357-366. doi:10.1016/j.aprim.2013.11.003

38. Tricco A, Lillie E, Zarin W et al. PRISMA Extension for Scoping Reviews (PRISMA-ScR): Checklist and Explanation. Ann Intern Med . 2018;169(7):467. doi:10.7326/m18-0850

39. Munn Z, Peters M, Stern C, Tufanaru C, McArthur A, Aromataris E. Systematic review or scoping review? Guidance for authors when choosing between a systematic or scoping review approach. BMC Med Res Methodol . 2018;18(1). doi:10.1186/s12874-018-0611-x

40. Hong Q, Fàbregues S, Bartlett G et al. The Mixed Methods Appraisal Tool (MMAT) version 2018 for information professionals and researchers. Education for Information . 2018;34(4):285-291. doi:10.3233/efi-180221

41. Scott S, Rotter T, Flynn R et al. Systematic review of the use of process evaluations in knowledge translation research. Syst Rev . 2019;8(1). doi:10.1186/s13643-019-1161-y

42. Al-Jumah K, Ahmad Hassali A, AlQhatani S. Examining the relationship between adherence and satisfaction with antidepressant treatment. Neuropsychiatr Dis Treat . 2014:1433. doi:10.2147/ndt.s67008

43. Aljumah K, Hassali M. Impact of pharmacist intervention on adherence and measurable patient outcomes among depressed patients: a randomised controlled study. BMC Psychiatry . 2015;15(1). doi:10.1186/s12888-015-0605-8

44. Baeza-Velasco C, Olié E, Béziat S, Guillaume S, Courtet P. Determinants of suboptimal medication adherence in patients with a major depressive episode. Depress Anxiety . 2018;36(3):244-251. doi:10.1002/da. 22852

45. Bhat S, Kroehl M, Trinkley K et al. Evaluation of a Clinical Pharmacist-Led Multidisciplinary Antidepressant Telemonitoring Service in the Primary Care Setting. Popul Health Manag . 2018;21(5):366-372. doi:10.1089/pop.2017.0144

46. Burnett-Zeigler I, Kim H, Chiang $\mathrm{C}$ et al. The association between race and gender, treatment attitudes, and antidepressant treatment adherence. Int J Geriatr Psychiatry . 2013;29(2):169-177. doi:10.1002/gps.3984

47. Chatterjee S, Chatterjee A, Dogra A, Gupta S. Role of Belief about and Adherence to Medication on Symptom Severity of Life of Patients Suffering from Depressive Disorder Residing a Rural Areas of West Bengal. Eastern Journal of Psychiatry . 2017;19(2).

48. De las Cuevas C, Peñate W, Sanz E. Risk factors for non-adherence to antidepressant treatment in patients with mood disorders. Eur J Clin Pharmacol . 2013;70(1):89-98. doi:10.1007/s00228-013-1582-9

49. De las Cuevas C, Peñate W, Sanz E. The relationship of psychological reactance, health locus of control and sense of self-efficacy with adherence to treatment in psychiatric outpatients with depression. BMC Psychiatry . 2014;14(1). doi:10.1186/s12888-014-0324-6

50. Isa E, Ani C, Bella-Awusah T, Omigbodun O. Effects of psycho-education plus basic cognitive behavioural therapy strategies on medication-treated adolescents with depressive disorder in Nigeria. Journal of Child \& Adolescent Mental Health . 2018;30(1):11-18. doi:10.2989/17280583.2018.1424634

51. Klein N, van Rijsbergen G, ten Doesschate M, Hollon S, Burger H, Bockting C. Beliefs about the causes of depression and recovery and their impact on adherence, dosage, and successful tapering of antidepressants. Depress Anxiety . 2017;34(3):227-235. doi:10.1002/da.22598

52. Lu Y, Arthur D, Hu L, Cheng G, An F, Li Z. Beliefs about antidepressant medication and associated adherence among older Chinese patients with major depression: A cross-sectional survey. Int $J$ Ment Health Nurs . 2015;25(1):71-79. doi:10.1111/inm.12181

53. Lucca J, Ramesh M, Parthasarathi G, Ram D. Incidence and factors associated with medication nonadherence in patients with mental illness: A cross-sectional study. J Postgrad Med . 2015;61(4):251. 
doi:10.4103/0022-3859.166514

54. Novick D, Montgomery W, Moneta V, Peng X, Brugnoli R, Haro J. Antidepressant medication treatment patterns in Asian patients with major depressive disorder. Patient Prefer Adherence . 2015:421. doi: $10.2147 /$ ppa.s68432

55. Serrano M, Vives M, Mateu C et al. Therapeutic adherence in primary care depressed patients: a longitudinal study. Actas Esp Psiquiatr . 2014;42(3):91-8.

56. Shrestha Manandhar J, Shrestha R, Basnet N et al. Study of Adherence Pattern of Antidepressants in Patients with Depression. Kathmandu University Medical Journal . 2017;15(57):3-9.

57. Taleban R, Zamani A, Moafi M, Jiryaee N, Khadivi R. Applications of text messaging, and bibliotherapy for treatment of patients affected by depressive symptoms. Int J Prev Med . 2016;7(1):46. doi:10.4103/2008-7802.177889

58. Vannachavee U, Seeherunwong A, Yuttatri P, Chulakadabba S. The Effect of a Drug Adherence Enhancement Program on the Drug Adherence Behaviors of Patients With Major Depressive Disorder in Thailand: A Randomized Clinical Trial. Arch Psychiatr Nurs . 2016;30(3):322-328. doi:10.1016/j.apnu.2015.12.001

59. Bushnell G, Stürmer T, White A et al. Predicting persistence to antidepressant treatment in administrative claims data: Considering the influence of refill delays and prior persistence on other medications. $J$ Affect Disord . 2016;196:138-147. doi:10.1016/j.jad.2016.02.012

60. Green B, Watson M, Kaltman S et al. Knowledge and Preferences Regarding Antidepressant Medication Among Depressed Latino Patients in Primary Care. J Nerv Ment Dis . 2017;205(12):952-959. doi:10.1097/nmd.0000000000000754

61. Grover S, Mehra A, Chakrabarti S, Avasthi A. Dropout rates and reasons for dropout from treatment among elderly patients with depression. Journal of Geriatric Mental Health . 2018;5(2):121. doi:10.4103/jgmh.jgmh_29_17

62. Holvast F, Oude Voshaar R, Wouters H et al. Non-adherence to antidepressants among older patients with depression: a longitudinal cohort study in primary care. Fam Pract . 2018;36(1):12-20. doi:10.1093/fampra/cmy106

63. Klang S, Ben-Amnon Y, Cohen Y, Barak Y. Community pharmacists' support improves antidepressant adherence in the community. Int Clin Psychopharmacol . 2015;30(6):316-319. doi:10.1097/yic.0000000000000090

64. LeBlanc A, Herrin J, Williams M et al. Shared Decision Making for Antidepressants in Primary Care. JAMA Intern Med . 2015;175(11):1761. doi:10.1001/jamainternmed.2015.5214

65. Slabbert F, Harvey B, Brink C, Lubbe M. Prospective analysis of the medicine possession ratio of antidepressants in the private health sector of South Africa, 2006 - 2011. South African Medical Journal . 2015;105(2):139. doi:10.7196/samj.8394

66. Zhang L, Chen Y, Yue L et al. Medication use patterns, health care resource utilization, and economic burden for patients with major depressive disorder in Beijing, People's Republic of China. Neuropsychiatr Dis Treat . 2016:941. doi:10.2147/ndt.s97407

67. Hammonds T, Rickert K, Goldstein C et al. Adherence to Antidepressant Medications: A Randomized Controlled Trial of Medication Reminding in College Students. Journal of American College Health . 2015;63(3):204-208. doi:10.1080/07448481.2014.975716

68. Pradeep J, Isaacs A, Shanbag D, Selvan S, Srinivasan K. Enhanced care by community health workers in improving treatment adherence to antidepressant medication in rural women with major depression. Indian J Med Res . 2014;139(2):236-245.

69. Srimongkon P, Aslani P, Chen T. Consumer-related factors influencing antidepressant adherence in unipolar depression: a qualitative study. Patient Prefer Adherence . 2018;Volume 12:1863-1873. doi:10.2147/ppa.s160728

70. Vargas S, Cabassa L, Nicasio A et al. Toward a cultural adaptation of pharmacotherapy: Latino views of depression and antidepressant therapy. Transcult Psychiatry . 2015;52(2):244-273. doi: $10.1177 / 1363461515574159$

71. Cochrane Effective Practice and Organisation of Care Review Group 
(EPOC). Data Collection Checklist . Epoc.cochrane.org: Cochrane; 2002. http://epoc.cochrane.org/sites/epoc.cochrane.org/files/public/uploads/datacollectionchecklist.pdf. Accessed November 14, 2019.

Table 1. Characteristics of Selected Studies $(\mathrm{n}=36)$

\begin{tabular}{|c|c|c|c|c|c|c|c|}
\hline $\begin{array}{l}\text { Author } \\
\text { (year) }\end{array}$ & Country & $\begin{array}{l}\text { Study } \\
\text { design }\end{array}$ & $\begin{array}{l}\text { Study } \\
\text { setting }\end{array}$ & 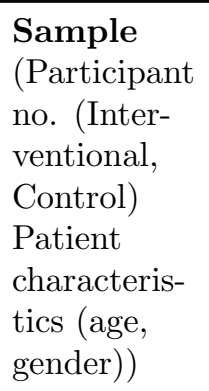 & $\begin{array}{l}\text { Sample } \\
\text { (Participant } \\
\text { no. (Inter- } \\
\text { ventional, } \\
\text { Control) } \\
\text { Patient } \\
\text { characteris- } \\
\text { tics (age, } \\
\text { gender)) }\end{array}$ & $\begin{array}{l}\text { Purpose of } \\
\text { study }\end{array}$ & $\begin{array}{l}\text { Outcome } \\
\text { variables }\end{array}$ \\
\hline & & & & $\begin{array}{l}\mathrm{n}=\text { sample } \\
\text { size }\end{array}$ & $\mathrm{I}: \mathrm{C}$ & & \\
\hline $\begin{array}{l}\text { Sirey et al. } \\
(2017)^{19}\end{array}$ & USA & $\begin{array}{l}\text { Quantitative } \\
\text { (Random- } \\
\text { ized } \\
\text { clinical ef- } \\
\text { fectiveness } \\
\text { trial) }\end{array}$ & Outpatient & 231 & $(115,116)$ & $\begin{array}{l}\text { The } \\
\text { purpose to } \\
\text { test the ef- } \\
\text { fectiveness } \\
\text { of TIP to } \\
\text { improve } \\
\text { early } \\
\text { adherence } \\
\text { among } \\
\text { older } \\
\text { patients } \\
\text { whose } \\
\text { primary } \\
\text { care } \\
\text { physician } \\
\text { newly } \\
\text { initiated } \\
\text { an antide- } \\
\text { pressant } \\
\text { for } \\
\text { depression. }\end{array}$ & $\begin{array}{l}\text { Medication } \\
\text { adherence } \\
\text { and } \\
\text { depression } \\
\text { severity }\end{array}$ \\
\hline $\begin{array}{l}\text { Alekhya et } \\
\text { al. } \\
(2015)^{21}\end{array}$ & India & $\begin{array}{l}\text { Quantitative } \\
\text { (Cross } \\
\text { sectional } \\
\text { study) }\end{array}$ & Outpatient & 103 & & $\begin{array}{l}\text { Study the } \\
\text { treatment } \\
\text { and } \\
\text { disease } \\
\text { factors } \\
\text { that } \\
\text { influence } \\
\text { compli- } \\
\text { ance to } \\
\text { the } \\
\text { treatment } \\
\text { of } \\
\text { depression. }\end{array}$ & $\begin{array}{l}\text { Medication } \\
\text { adherence; } \\
\text { and } \\
\text { disease } \\
\text { and } \\
\text { treatment } \\
\text { factors }\end{array}$ \\
\hline
\end{tabular}




\begin{tabular}{|c|c|c|c|c|c|c|c|}
\hline $\begin{array}{l}\text { Author } \\
\text { (year) }\end{array}$ & Country & $\begin{array}{l}\text { Study } \\
\text { design }\end{array}$ & $\begin{array}{l}\text { Study } \\
\text { setting }\end{array}$ & $\begin{array}{l}\text { Sample } \\
\text { (Participant } \\
\text { no. (Inter- } \\
\text { ventional, } \\
\text { Control) } \\
\text { Patient } \\
\text { characteris- } \\
\text { tics (age, } \\
\text { gender)) }\end{array}$ & $\begin{array}{l}\text { Sample } \\
\text { (Participant } \\
\text { no. (Inter- } \\
\text { ventional, } \\
\text { Control) } \\
\text { Patient } \\
\text { characteris- } \\
\text { tics (age, } \\
\text { gender)) }\end{array}$ & $\begin{array}{l}\text { Purpose of } \\
\text { study }\end{array}$ & $\begin{array}{l}\text { Outcome } \\
\text { variables }\end{array}$ \\
\hline $\begin{array}{l}\text { Abegaz et } \\
\text { al. } \\
(2017)^{22}\end{array}$ & Ethiopia & $\begin{array}{l}\text { Quantitative } \\
\text { (Prospec- } \\
\text { tive } \\
\text { cross- } \\
\text { sectional } \\
\text { study) }\end{array}$ & $\begin{array}{l}\text { Inpatient } \\
\text { and } \\
\text { outpatient }\end{array}$ & 270 & & $\begin{array}{l}\text { The } \\
\text { purpose to } \\
\text { determine } \\
\text { the degree } \\
\text { of adverse } \\
\text { drug } \\
\text { reactions } \\
\text { of antide- } \\
\text { pressants } \\
\text { and their } \\
\text { impact on } \\
\text { the level } \\
\text { of } \\
\text { adherence } \\
\text { and } \\
\text { clinical } \\
\text { outcome. }\end{array}$ & $\begin{array}{l}\text { Adverse } \\
\text { drug } \\
\text { reactions, } \\
\text { medica- } \\
\text { tion } \\
\text { adherence, } \\
\text { and } \\
\text { clinical } \\
\text { outcomes } \\
\text { (depression) }\end{array}$ \\
\hline $\begin{array}{l}\text { Al-Jumah } \\
\text { et al. } \\
(2014)^{23}\end{array}$ & $\begin{array}{l}\text { Saudi } \\
\text { Arabia }\end{array}$ & $\begin{array}{l}\text { Quantitative } \\
\text { (Non- } \\
\text { experimental } \\
\text { cross- } \\
\text { sectional } \\
\text { design) }\end{array}$ & Outpatient & 403 & & $\begin{array}{l}\text { The } \\
\text { purpose to } \\
\text { explore } \\
\text { patients' } \\
\text { adherence } \\
\text { to antide- } \\
\text { pressant } \\
\text { medica- } \\
\text { tion, and } \\
\text { the factors } \\
\text { associated } \\
\text { with } \\
\text { adherence } \\
\text { among } \\
\text { patients } \\
\text { with } \\
\text { depression. }\end{array}$ & $\begin{array}{l}\text { Medication } \\
\text { adherence } \\
\text { and beliefs } \\
\text { about } \\
\text { medication }\end{array}$ \\
\hline
\end{tabular}




\begin{tabular}{|c|c|c|c|c|c|c|c|}
\hline $\begin{array}{l}\text { Author } \\
\text { (year) }\end{array}$ & Country & $\begin{array}{l}\text { Study } \\
\text { design }\end{array}$ & $\begin{array}{l}\text { Study } \\
\text { setting }\end{array}$ & $\begin{array}{l}\text { Sample } \\
\text { (Participant } \\
\text { no. (Inter- } \\
\text { ventional, } \\
\text { Control) } \\
\text { Patient } \\
\text { characteris- } \\
\text { tics (age, } \\
\text { gender)) }\end{array}$ & $\begin{array}{l}\text { Sample } \\
\text { (Participant } \\
\text { no. (Inter- } \\
\text { ventional, } \\
\text { Control) } \\
\text { Patient } \\
\text { characteris- } \\
\text { tics (age, } \\
\text { gender)) }\end{array}$ & $\begin{array}{l}\text { Purpose of } \\
\text { study }\end{array}$ & $\begin{array}{l}\text { Outcome } \\
\text { variables }\end{array}$ \\
\hline $\begin{array}{l}\text { Ho et al. } \\
(2017)^{24}\end{array}$ & Malaysia & $\begin{array}{l}\text { Qualitative } \\
\text { (Grounded } \\
\text { theory } \\
\text { methodology) }\end{array}$ & Outpatient & 30 & & $\begin{array}{l}\text { The } \\
\text { purpose to } \\
\text { explore } \\
\text { the } \\
\text { barriers } \\
\text { and } \\
\text { facilitators } \\
\text { of } \\
\text { patients' } \\
\text { adherence } \\
\text { to antide- } \\
\text { pressants } \\
\text { among } \\
\text { outpa- } \\
\text { tients with } \\
\text { MDD. }\end{array}$ & $\begin{array}{l}\text { Barriers } \\
\text { and } \\
\text { facilitators } \\
\text { of medica- } \\
\text { tion } \\
\text { adherence }\end{array}$ \\
\hline $\begin{array}{l}\text { Yau et al. } \\
(2014)^{25}\end{array}$ & China & $\begin{array}{l}\text { Quantitative } \\
\text { (Retro- } \\
\text { spective } \\
\text { cohort } \\
\text { study) }\end{array}$ & Outpatient & 189 & & $\begin{array}{l}\text { The } \\
\text { purpose to } \\
\text { investigate } \\
\text { the rate of } \\
\text { noncontin- } \\
\text { uous } \\
\text { antide- } \\
\text { pressant } \\
\text { use, subse- } \\
\text { quent rate } \\
\text { of relapse } \\
\text { and } \\
\text { recurrence } \\
\text { in psychi- } \\
\text { atric } \\
\text { Chinese } \\
\text { outpa- } \\
\text { tients, and } \\
\text { factors } \\
\text { associated } \\
\text { with non- } \\
\text { continuous } \\
\text { antide- } \\
\text { pressant } \\
\text { use. }\end{array}$ & $\begin{array}{l}\text { noncontinuous } \\
\text { antide- } \\
\text { pressant } \\
\text { use, } \\
\text { factors } \\
\text { associated } \\
\text { with non- } \\
\text { continuous } \\
\text { antide- } \\
\text { pressant, } \\
\text { and subse- } \\
\text { quent } \\
\text { depression } \\
\text { relapse } \\
\text { and } \\
\text { recurrence }\end{array}$ \\
\hline
\end{tabular}




\begin{tabular}{|c|c|c|c|c|c|c|c|}
\hline $\begin{array}{l}\text { Author } \\
\text { (year) }\end{array}$ & Country & $\begin{array}{l}\text { Study } \\
\text { design }\end{array}$ & $\begin{array}{l}\text { Study } \\
\text { setting }\end{array}$ & $\begin{array}{l}\text { Sample } \\
\text { (Participant } \\
\text { no. (Inter- } \\
\text { ventional, } \\
\text { Control) } \\
\text { Patient } \\
\text { characteris- } \\
\text { tics (age, } \\
\text { gender)) }\end{array}$ & $\begin{array}{l}\text { Sample } \\
\text { (Participant } \\
\text { no. (Inter- } \\
\text { ventional, } \\
\text { Control) } \\
\text { Patient } \\
\text { characteris- } \\
\text { tics (age, } \\
\text { gender)) }\end{array}$ & $\begin{array}{l}\text { Purpose of } \\
\text { study }\end{array}$ & $\begin{array}{l}\text { Outcome } \\
\text { variables }\end{array}$ \\
\hline $\begin{array}{l}\text { Mert et al. } \\
(2015)^{34}\end{array}$ & Turkey & $\begin{array}{l}\text { Quantitative } \\
\text { (Cross- } \\
\text { sectional } \\
\text { study) }\end{array}$ & Inpatient & $\begin{array}{l}203(\mathrm{n}=39 \\
\text { patients } \\
\text { with } \\
\text { depression })\end{array}$ & & $\begin{array}{l}\text { The } \\
\text { purpose to } \\
\text { evaluate } \\
\text { factors } \\
\text { resulting } \\
\text { in medica- } \\
\text { tion } \\
\text { nonadher- } \\
\text { ence } \\
\text { before } \\
\text { admission } \\
\text { to the psy- } \\
\text { chiatric } \\
\text { service for } \\
\text { patients } \\
\text { with psy- } \\
\text { chiatric } \\
\text { disorder. }\end{array}$ & $\begin{array}{l}\text { Socio- } \\
\text { demographic } \\
\text { and } \\
\text { clinical } \\
\text { variables, } \\
\text { medica- } \\
\text { tion } \\
\text { adherence, } \\
\text { and } \\
\text { reasons of } \\
\text { medica- } \\
\text { tion } \\
\text { nonadherence }\end{array}$ \\
\hline $\begin{array}{l}\text { Al-Jumah } \\
\text { et al. } \\
(2014)^{46}\end{array}$ & $\begin{array}{l}\text { Saudi } \\
\text { Arabia }\end{array}$ & $\begin{array}{l}\text { Quantitative } \\
\text { (Non- } \\
\text { experimental, } \\
\text { observa- } \\
\text { tional } \\
\text { design) }\end{array}$ & Outpatient & 403 & & $\begin{array}{l}\text { The } \\
\text { purpose to } \\
\text { investigate } \\
\text { the rela- } \\
\text { tionship } \\
\text { between } \\
\text { patient } \\
\text { treatment } \\
\text { satisfac- } \\
\text { tion and } \\
\text { adherence } \\
\text { to antide- } \\
\text { pressants, } \\
\text { and the } \\
\text { role of } \\
\text { patient } \\
\text { beliefs } \\
\text { toward } \\
\text { medica- } \\
\text { tion in } \\
\text { patient } \\
\text { treatment } \\
\text { satisfaction. }\end{array}$ & $\begin{array}{l}\text { Medication } \\
\text { adherence, } \\
\text { treatment } \\
\text { satisfac- } \\
\text { tion, and } \\
\text { beliefs } \\
\text { about } \\
\text { medication }\end{array}$ \\
\hline
\end{tabular}




\begin{tabular}{|c|c|c|c|c|c|c|c|}
\hline $\begin{array}{l}\text { Author } \\
\text { (year) }\end{array}$ & Country & $\begin{array}{l}\text { Study } \\
\text { design }\end{array}$ & $\begin{array}{l}\text { Study } \\
\text { setting }\end{array}$ & $\begin{array}{l}\text { Sample } \\
\text { (Participant } \\
\text { no. (Inter- } \\
\text { ventional, } \\
\text { Control) } \\
\text { Patient } \\
\text { characteris- } \\
\text { tics (age, } \\
\text { gender)) }\end{array}$ & $\begin{array}{l}\text { Sample } \\
\text { (Participant } \\
\text { no. (Inter- } \\
\text { ventional, } \\
\text { Control) } \\
\text { Patient } \\
\text { characteris- } \\
\text { tics (age, } \\
\text { gender)) }\end{array}$ & $\begin{array}{l}\text { Purpose of } \\
\text { study }\end{array}$ & $\begin{array}{l}\text { Outcome } \\
\text { variables }\end{array}$ \\
\hline $\begin{array}{l}\text { Aljumah } \\
\text { and } \\
\text { Hassali } \\
(2015)^{47}\end{array}$ & $\begin{array}{l}\text { Saudi } \\
\text { Arabia }\end{array}$ & $\begin{array}{l}\text { Quantitative } \\
\text { (Prospec- } \\
\text { tive } \\
\text { random- } \\
\text { ized } \\
\text { controlled } \\
\text { study) }\end{array}$ & Outpatient & 239 & $(119,120)$ & $\begin{array}{l}\text { The } \\
\text { purpose to } \\
\text { assess } \\
\text { whether } \\
\text { pharma- } \\
\text { cist } \\
\text { interven- } \\
\text { tions } \\
\text { based on } \\
\text { SDM } \\
\text { improved } \\
\text { adherence } \\
\text { and } \\
\text { patient- } \\
\text { related } \\
\text { outcomes. }\end{array}$ & $\begin{array}{l}\text { Medication } \\
\text { adherence, } \\
\text { beliefs } \\
\text { about } \\
\text { medica- } \\
\text { tion, } \\
\text { clinical } \\
\text { outcomes } \\
\text { (depres- } \\
\text { sion } \\
\text { symp- } \\
\text { toms), } \\
\text { patient in- } \\
\text { volvement } \\
\text { in } \\
\text { decision- } \\
\text { making, } \\
\text { quality of } \\
\text { life, and } \\
\text { treatment } \\
\text { satisfaction }\end{array}$ \\
\hline
\end{tabular}




\begin{tabular}{|c|c|c|c|c|c|c|c|}
\hline $\begin{array}{l}\text { Author } \\
\text { (year) }\end{array}$ & Country & $\begin{array}{l}\text { Study } \\
\text { design }\end{array}$ & $\begin{array}{l}\text { Study } \\
\text { setting }\end{array}$ & $\begin{array}{l}\text { Sample } \\
\text { (Participant } \\
\text { no. (Inter- } \\
\text { ventional, } \\
\text { Control) } \\
\text { Patient } \\
\text { characteris- } \\
\text { tics (age, } \\
\text { gender)) }\end{array}$ & $\begin{array}{l}\text { Sample } \\
\text { (Participant } \\
\text { no. (Inter- } \\
\text { ventional, } \\
\text { Control) } \\
\text { Patient } \\
\text { characteris- } \\
\text { tics (age, } \\
\text { gender)) }\end{array}$ & $\begin{array}{l}\text { Purpose of } \\
\text { study }\end{array}$ & $\begin{array}{l}\text { Outcome } \\
\text { variables }\end{array}$ \\
\hline $\begin{array}{l}\text { Baeza- } \\
\text { Velasco et } \\
\text { al. } \\
(2019)^{48}\end{array}$ & France & $\begin{array}{l}\text { Quantitative } \\
\text { (Cross- } \\
\text { sectional } \\
\text { study) }\end{array}$ & $\begin{array}{l}\text { Inpatient } \\
\text { and } \\
\text { outpatient }\end{array}$ & 360 & & $\begin{array}{l}\text { The } \\
\text { purpose to } \\
\text { explore } \\
\text { medica- } \\
\text { tion } \\
\text { adherence } \\
\text { in patients } \\
\text { with a } \\
\text { major } \\
\text { depression } \\
\text { episode, } \\
\text { and to } \\
\text { identify } \\
\text { sociode- } \\
\text { mo- } \\
\text { graphic, } \\
\text { clinical, } \\
\text { and psy- } \\
\text { chosocial } \\
\text { factors } \\
\text { related to } \\
\text { adherence } \\
\text { status. }\end{array}$ & $\begin{array}{l}\text { Medication } \\
\text { adherence, } \\
\text { clinical } \\
\text { and psy- } \\
\text { chosocial } \\
\text { factors } \\
\text { (depres- } \\
\text { sive } \\
\text { symp- } \\
\text { toms, } \\
\text { psychi- } \\
\text { atric } \\
\text { an- } \\
\text { tecedents, } \\
\text { comorbidi- } \\
\text { ties, } \\
\text { medica- } \\
\text { tion, pain, } \\
\text { medica- } \\
\text { tion side } \\
\text { effects, } \\
\text { negative } \\
\text { life events, } \\
\text { childhood } \\
\text { trauma, } \\
\text { and } \\
\text { attitudes } \\
\text { to } \\
\text { medication) }\end{array}$ \\
\hline
\end{tabular}




\begin{tabular}{|c|c|c|c|c|c|c|c|}
\hline $\begin{array}{l}\text { Author } \\
\text { (year) }\end{array}$ & Country & $\begin{array}{l}\text { Study } \\
\text { design }\end{array}$ & $\begin{array}{l}\text { Study } \\
\text { setting }\end{array}$ & $\begin{array}{l}\text { Sample } \\
\text { (Participant } \\
\text { no. (Inter- } \\
\text { ventional, } \\
\text { Control) } \\
\text { Patient } \\
\text { characteris- } \\
\text { tics (age, } \\
\text { gender)) }\end{array}$ & $\begin{array}{l}\text { Sample } \\
\text { (Participant } \\
\text { no. (Inter- } \\
\text { ventional, } \\
\text { Control) } \\
\text { Patient } \\
\text { characteris- } \\
\text { tics (age, } \\
\text { gender)) }\end{array}$ & $\begin{array}{l}\text { Purpose of } \\
\text { study }\end{array}$ & $\begin{array}{l}\text { Outcome } \\
\text { variables }\end{array}$ \\
\hline $\begin{array}{l}\text { Bhat et al. } \\
(2018)^{49}\end{array}$ & USA & $\begin{array}{l}\text { Quantitative } \\
\text { (Observa- } \\
\text { tional } \\
\text { retrospec- } \\
\text { tive cohort } \\
\text { study) }\end{array}$ & Outpatient & 258 & & $\begin{array}{l}\text { The } \\
\text { purpose to } \\
\text { evaluate } \\
\text { the } \\
\text { feasibility } \\
\text { of imple- } \\
\text { menting a } \\
\text { clinical } \\
\text { pharma- } \\
\text { cist led } \\
\text { multidisci- } \\
\text { plinary } \\
\text { antide- } \\
\text { pressant } \\
\text { telemoni- } \\
\text { toring } \\
\text { service, } \\
\text { evaluate } \\
\text { potential } \\
\text { opportuni- } \\
\text { ties for } \\
\text { clinical } \\
\text { pharmacy } \\
\text { interven- } \\
\text { tion, and } \\
\text { identify } \\
\text { which } \\
\text { patients } \\
\text { with } \\
\text { major } \\
\text { depressive } \\
\text { disorder } \\
\text { would be } \\
\text { most } \\
\text { likely to } \\
\text { benefit } \\
\text { from this } \\
\text { service in } \\
\text { primary } \\
\text { care. }\end{array}$ & $\begin{array}{l}\text { Medication } \\
\text { adherence, } \\
\text { adverse } \\
\text { effects, } \\
\text { suicidal } \\
\text { ideations, } \\
\text { depressive } \\
\text { symp- } \\
\text { toms, and } \\
\text { pharma- } \\
\text { cist } \\
\text { interventions. }\end{array}$ \\
\hline
\end{tabular}




\begin{tabular}{|c|c|c|c|c|c|c|c|}
\hline $\begin{array}{l}\text { Author } \\
\text { (year) }\end{array}$ & Country & $\begin{array}{l}\text { Study } \\
\text { design }\end{array}$ & $\begin{array}{l}\text { Study } \\
\text { setting }\end{array}$ & $\begin{array}{l}\text { Sample } \\
\text { (Participant } \\
\text { no. (Inter- } \\
\text { ventional, } \\
\text { Control) } \\
\text { Patient } \\
\text { characteris- } \\
\text { tics (age, } \\
\text { gender)) }\end{array}$ & $\begin{array}{l}\text { Sample } \\
\text { (Participant } \\
\text { no. (Inter- } \\
\text { ventional, } \\
\text { Control) } \\
\text { Patient } \\
\text { characteris- } \\
\text { tics (age, } \\
\text { gender)) }\end{array}$ & $\begin{array}{l}\text { Purpose of } \\
\text { study }\end{array}$ & $\begin{array}{l}\text { Outcome } \\
\text { variables }\end{array}$ \\
\hline $\begin{array}{l}\text { Burnett- } \\
\text { Zeigler et } \\
\text { al. } \\
(2014)^{50}\end{array}$ & USA & $\begin{array}{l}\text { Quantitative } \\
\text { (Prospec- } \\
\text { tive, } \\
\text { observa- } \\
\text { tional } \\
\text { study) }\end{array}$ & Outpatient & 186 & & $\begin{array}{l}\text { The } \\
\text { purpose to } \\
\text { examine } \\
\text { the associ- } \\
\text { ations } \\
\text { between } \\
\text { treatment } \\
\text { attitudes } \\
\text { and beliefs } \\
\text { with race-- } \\
\text { gender } \\
\text { differences } \\
\text { in antide- } \\
\text { pressant } \\
\text { adherence. }\end{array}$ & $\begin{array}{l}\text { Medication } \\
\text { adherence, } \\
\text { demo- } \\
\text { graphic } \\
\text { variables, } \\
\text { illness } \\
\text { variables } \\
\text { (past } \\
\text { antide- } \\
\text { pressant } \\
\text { use, } \\
\text { number of } \\
\text { prescribed } \\
\text { medica- } \\
\text { tions, } \\
\text { physical } \\
\text { health } \\
\text { status, } \\
\text { mental } \\
\text { health } \\
\text { status, } \\
\text { comorbid } \\
\text { anxiety, } \\
\text { somatic } \\
\text { anxiety, } \\
\text { and de- } \\
\text { pression), } \\
\text { activities } \\
\text { of daily } \\
\text { living and } \\
\text { executive } \\
\text { function, } \\
\text { attitudes } \\
\text { and beliefs } \\
\text { toward } \\
\text { depression } \\
\text { treatment, } \\
\text { and } \\
\text { stigma }\end{array}$ \\
\hline
\end{tabular}




\begin{tabular}{|c|c|c|c|c|c|c|c|}
\hline $\begin{array}{l}\text { Author } \\
\text { (year) }\end{array}$ & Country & $\begin{array}{l}\text { Study } \\
\text { design }\end{array}$ & $\begin{array}{l}\text { Study } \\
\text { setting }\end{array}$ & $\begin{array}{l}\text { Sample } \\
\text { (Participant } \\
\text { no. (Inter- } \\
\text { ventional, } \\
\text { Control) } \\
\text { Patient } \\
\text { characteris- } \\
\text { tics (age, } \\
\text { gender)) }\end{array}$ & $\begin{array}{l}\text { Sample } \\
\text { (Participant } \\
\text { no. (Inter- } \\
\text { ventional, } \\
\text { Control) } \\
\text { Patient } \\
\text { characteris- } \\
\text { tics (age, } \\
\text { gender)) }\end{array}$ & $\begin{array}{l}\text { Purpose of } \\
\text { study }\end{array}$ & $\begin{array}{l}\text { Outcome } \\
\text { variables }\end{array}$ \\
\hline $\begin{array}{l}\text { Chatterjee } \\
\text { et al. } \\
(2017)^{51}\end{array}$ & India & $\begin{array}{l}\text { Quantitative } \\
\text { (Ex-post } \\
\text { facto } \\
\text { design } \\
\text { (criterion- } \\
\text { group } \\
\text { design)) }\end{array}$ & Outpatient & 60 & & $\begin{array}{l}\text { The } \\
\text { purpose to } \\
\text { explore } \\
\text { belief } \\
\text { about the } \\
\text { medica- } \\
\text { tion } \\
\text { influences } \\
\text { adherence } \\
\text { to medica- } \\
\text { tion, and } \\
\text { influence } \\
\text { severity of } \\
\text { depression } \\
\text { and } \\
\text { quality of } \\
\text { life of } \\
\text { patients } \\
\text { with MDD } \\
\text { residing at } \\
\text { urban and } \\
\text { rural } \\
\text { areas. }\end{array}$ & $\begin{array}{l}\text { Medication } \\
\text { adherence, } \\
\text { beliefs } \\
\text { about } \\
\text { medica- } \\
\text { tion, } \\
\text { depressive } \\
\text { symp- } \\
\text { toms, and } \\
\text { quality of } \\
\text { life }\end{array}$ \\
\hline
\end{tabular}




\begin{tabular}{|c|c|c|c|c|c|c|c|}
\hline $\begin{array}{l}\text { Author } \\
\text { (year) }\end{array}$ & Country & $\begin{array}{l}\text { Study } \\
\text { design }\end{array}$ & $\begin{array}{l}\text { Study } \\
\text { setting }\end{array}$ & $\begin{array}{l}\text { Sample } \\
\text { (Participant } \\
\text { no. (Inter- } \\
\text { ventional, } \\
\text { Control) } \\
\text { Patient } \\
\text { characteris- } \\
\text { tics (age, } \\
\text { gender)) }\end{array}$ & $\begin{array}{l}\text { Sample } \\
\text { (Participant } \\
\text { no. (Inter- } \\
\text { ventional, } \\
\text { Control) } \\
\text { Patient } \\
\text { characteris- } \\
\text { tics (age, } \\
\text { gender)) }\end{array}$ & $\begin{array}{l}\text { Purpose of } \\
\text { study }\end{array}$ & $\begin{array}{l}\text { Outcome } \\
\text { variables }\end{array}$ \\
\hline $\begin{array}{l}\text { De las } \\
\text { Cuevas et } \\
\text { al. } \\
(2014)^{52}\end{array}$ & Spain & $\begin{array}{l}\text { Quantitative } \\
\text { (Cross- } \\
\text { sectional } \\
\text { study) }\end{array}$ & Outpatient & 145 & & $\begin{array}{l}\text { The } \\
\text { purpose to } \\
\text { identify } \\
\text { potential } \\
\text { factors in- } \\
\text { fluencing } \\
\text { adherence } \\
\text { to antide- } \\
\text { pressant } \\
\text { treatment } \\
\text { by } \\
\text { patients } \\
\text { with mood } \\
\text { disorders } \\
\text { in the } \\
\text { commu- } \\
\text { nity } \\
\text { mental } \\
\text { health } \\
\text { care } \\
\text { setting. }\end{array}$ & $\begin{array}{l}\text { Socio- } \\
\text { demographic } \\
\text { character- } \\
\text { istics and } \\
\text { clinical } \\
\text { variables, } \\
\text { medica- } \\
\text { tion } \\
\text { adherence, } \\
\text { attitudes } \\
\text { toward } \\
\text { treatment, } \\
\text { beliefs } \\
\text { about } \\
\text { medica- } \\
\text { tion, } \\
\text { attitude } \\
\text { toward } \\
\text { concor- } \\
\text { dance, } \\
\text { depressive } \\
\text { symp- } \\
\text { toms, and } \\
\text { side effect }\end{array}$ \\
\hline
\end{tabular}




\begin{tabular}{|c|c|c|c|c|c|c|c|}
\hline $\begin{array}{l}\text { Author } \\
\text { (year) }\end{array}$ & Country & $\begin{array}{l}\text { Study } \\
\text { design }\end{array}$ & $\begin{array}{l}\text { Study } \\
\text { setting }\end{array}$ & $\begin{array}{l}\text { Sample } \\
\text { (Participant } \\
\text { no. (Inter- } \\
\text { ventional, } \\
\text { Control) } \\
\text { Patient } \\
\text { characteris- } \\
\text { tics (age, } \\
\text { gender)) }\end{array}$ & $\begin{array}{l}\text { Sample } \\
\text { (Participant } \\
\text { no. (Inter- } \\
\text { ventional, } \\
\text { Control) } \\
\text { Patient } \\
\text { characteris- } \\
\text { tics (age, } \\
\text { gender)) }\end{array}$ & $\begin{array}{l}\text { Purpose of } \\
\text { study }\end{array}$ & $\begin{array}{l}\text { Outcome } \\
\text { variables }\end{array}$ \\
\hline $\begin{array}{l}\text { De Las } \\
\text { Cuevas et } \\
\text { al. } \\
(2014)^{53}\end{array}$ & Spain & $\begin{array}{l}\text { Quantitative } \\
\text { (Cross- } \\
\text { sectional } \\
\text { study) }\end{array}$ & Outpatient & 119 & & $\begin{array}{l}\text { The } \\
\text { purpose to } \\
\text { examine } \\
\text { the rela- } \\
\text { tionship of } \\
\text { psycholog- } \\
\text { ical } \\
\text { reactance, } \\
\text { health } \\
\text { locus of } \\
\text { control } \\
\text { and the } \\
\text { sense of } \\
\text { self- } \\
\text { efficacy on } \\
\text { adherence } \\
\text { to } \\
\text { treatment } \\
\text { regimen } \\
\text { among } \\
\text { psychi- } \\
\text { atric } \\
\text { outpa- } \\
\text { tients with } \\
\text { depression. }\end{array}$ & $\begin{array}{l}\text { Socio- } \\
\text { demographic } \\
\text { character- } \\
\text { istics and } \\
\text { clinical } \\
\text { variables, } \\
\text { medica- } \\
\text { tion } \\
\text { adherence, } \\
\text { psycholog- } \\
\text { ical } \\
\text { features } \\
\text { (psycho- } \\
\text { logical } \\
\text { reactance, } \\
\text { health } \\
\text { locus of } \\
\text { control, } \\
\text { and self- } \\
\text { efficacy) }\end{array}$ \\
\hline $\begin{array}{l}\text { Isa et al. } \\
(2018)^{54}\end{array}$ & Nigeria & $\begin{array}{l}\text { Quantitative } \\
\text { (Pre-post } \\
\text { one-group } \\
\text { interven- } \\
\text { tion } \\
\text { study) }\end{array}$ & Outpatient & 18 & & $\begin{array}{l}\text { The } \\
\text { purpose to } \\
\text { investigate } \\
\text { the effects } \\
\text { of psycho- } \\
\text { education } \\
\text { and basic } \\
\text { CBT in- } \\
\text { tervention } \\
\text { on } \\
\text { depressed } \\
\text { medication- } \\
\text { treated } \\
\text { adolescents. }\end{array}$ & $\begin{array}{l}\text { Depressive } \\
\text { symp- } \\
\text { toms, } \\
\text { knowledge } \\
\text { of depres- } \\
\text { sion, hope, } \\
\text { attitudes } \\
\text { towards } \\
\text { treatment } \\
\text { adherence, } \\
\text { and } \\
\text { satisfaction }\end{array}$ \\
\hline
\end{tabular}




\begin{tabular}{|c|c|c|c|c|c|c|c|}
\hline $\begin{array}{l}\text { Author } \\
\text { (year) }\end{array}$ & Country & $\begin{array}{l}\text { Study } \\
\text { design }\end{array}$ & $\begin{array}{l}\text { Study } \\
\text { setting }\end{array}$ & $\begin{array}{l}\text { Sample } \\
\text { (Participant } \\
\text { no. (Inter- } \\
\text { ventional, } \\
\text { Control) } \\
\text { Patient } \\
\text { characteris- } \\
\text { tics (age, } \\
\text { gender)) }\end{array}$ & $\begin{array}{l}\text { Sample } \\
\text { (Participant } \\
\text { no. (Inter- } \\
\text { ventional, } \\
\text { Control) } \\
\text { Patient } \\
\text { characteris- } \\
\text { tics (age, } \\
\text { gender)) }\end{array}$ & $\begin{array}{l}\text { Purpose of } \\
\text { study }\end{array}$ & $\begin{array}{l}\text { Outcome } \\
\text { variables }\end{array}$ \\
\hline $\begin{array}{l}\text { Klein et } \\
\text { al. } \\
(2017)^{55}\end{array}$ & Netherlands & $\begin{array}{l}\text { Quantitative } \\
\text { (Descrip- } \\
\text { tive } \\
\text { longitudi- } \\
\text { nal } \\
\text { study) }\end{array}$ & Outpatient & 289 & & $\begin{array}{l}\text { The } \\
\text { purpose to } \\
\text { explore } \\
\text { beliefs } \\
\text { about the } \\
\text { causes of } \\
\text { depression } \\
\text { and } \\
\text { recovery } \\
\text { and to } \\
\text { examine } \\
\text { whether } \\
\text { they } \\
\text { predict } \\
\text { antide- } \\
\text { pressant } \\
\text { medica- } \\
\text { tion } \\
\text { use. }\end{array}$ & $\begin{array}{l}\text { Medication } \\
\text { adherence, } \\
\text { beliefs } \\
\text { regarding } \\
\text { depres- } \\
\text { sion, and } \\
\text { antide- } \\
\text { pressant } \\
\text { medica- } \\
\text { tion } \\
\text { dosage }\end{array}$ \\
\hline
\end{tabular}




\begin{tabular}{|c|c|c|c|c|c|c|c|}
\hline $\begin{array}{l}\text { Author } \\
\text { (year) }\end{array}$ & Country & $\begin{array}{l}\text { Study } \\
\text { design }\end{array}$ & $\begin{array}{l}\text { Study } \\
\text { setting }\end{array}$ & $\begin{array}{l}\text { Sample } \\
\text { (Participant } \\
\text { no. (Inter- } \\
\text { ventional, } \\
\text { Control) } \\
\text { Patient } \\
\text { characteris- } \\
\text { tics (age, } \\
\text { gender)) }\end{array}$ & $\begin{array}{l}\text { Sample } \\
\text { (Participant } \\
\text { no. (Inter- } \\
\text { ventional, } \\
\text { Control) } \\
\text { Patient } \\
\text { characteris- } \\
\text { tics (age, } \\
\text { gender)) }\end{array}$ & $\begin{array}{l}\text { Purpose of } \\
\text { study }\end{array}$ & $\begin{array}{l}\text { Outcome } \\
\text { variables }\end{array}$ \\
\hline $\begin{array}{l}\text { Lu et al. } \\
(2016)^{56}\end{array}$ & China & $\begin{array}{l}\text { Quantitative } \\
\text { (Cross- } \\
\text { sectional } \\
\text { study) }\end{array}$ & Outpatient & 135 & & $\begin{array}{l}\text { The } \\
\text { purpose to } \\
\text { investigate } \\
\text { the } \\
\text { variables } \\
\text { associated } \\
\text { with } \\
\text { adherence } \\
\text { with } \\
\text { antide- } \\
\text { pressants } \\
\text { in elderly } \\
\text { Chinese } \\
\text { patients, } \\
\text { focusing } \\
\text { on } \\
\text { attitudes } \\
\text { and beliefs } \\
\text { as } \\
\text { potential } \\
\text { predictors, } \\
\text { as well as } \\
\text { sociode- } \\
\text { mographic } \\
\text { character- } \\
\text { istics and } \\
\text { illness- } \\
\text { related } \\
\text { variables. }\end{array}$ & $\begin{array}{l}\text { Medication } \\
\text { adherence } \\
\text { and beliefs } \\
\text { about } \\
\text { medication }\end{array}$ \\
\hline
\end{tabular}




\begin{tabular}{|c|c|c|c|c|c|c|c|}
\hline $\begin{array}{l}\text { Author } \\
\text { (year) }\end{array}$ & Country & $\begin{array}{l}\text { Study } \\
\text { design }\end{array}$ & $\begin{array}{l}\text { Study } \\
\text { setting }\end{array}$ & $\begin{array}{l}\text { Sample } \\
\text { (Participant } \\
\text { no. (Inter- } \\
\text { ventional, } \\
\text { Control) } \\
\text { Patient } \\
\text { characteris- } \\
\text { tics (age, } \\
\text { gender)) }\end{array}$ & $\begin{array}{l}\text { Sample } \\
\text { (Participant } \\
\text { no. (Inter- } \\
\text { ventional, } \\
\text { Control) } \\
\text { Patient } \\
\text { characteris- } \\
\text { tics (age, } \\
\text { gender)) }\end{array}$ & $\begin{array}{l}\text { Purpose of } \\
\text { study }\end{array}$ & $\begin{array}{l}\text { Outcome } \\
\text { variables }\end{array}$ \\
\hline $\begin{array}{l}\text { Lucca et } \\
\text { al. } \\
(2015)^{57}\end{array}$ & India & $\begin{array}{l}\text { Quantitative } \\
\text { (Cross- } \\
\text { sectional } \\
\text { study) }\end{array}$ & Outpatient & $\begin{array}{l}400 \\
(\mathrm{n}=170 \\
\text { patients } \\
\text { with } \\
\text { depression) }\end{array}$ & & $\begin{array}{l}\text { The } \\
\text { purpose to } \\
\text { determine } \\
\text { the } \\
\text { incidence } \\
\text { and } \\
\text { factors } \\
\text { associated } \\
\text { with med- } \\
\text { ication } \\
\text { nonadher- } \\
\text { ence } \\
\text { among } \\
\text { psychi- } \\
\text { atric } \\
\text { outpatients. }\end{array}$ & $\begin{array}{l}\text { Medication } \\
\text { adherence } \\
\text { and } \\
\text { reasons for } \\
\text { medica- } \\
\text { tion } \\
\text { nonadherence }\end{array}$ \\
\hline $\begin{array}{l}\text { Novick et } \\
\text { al. } \\
(2015)^{58}\end{array}$ & $\begin{array}{l}\text { Six East } \\
\text { Asian } \\
\text { countries } \\
\text { and } \\
\text { regions } \\
\text { (China, } \\
\text { Hong } \\
\text { Kong, } \\
\text { Malaysia, } \\
\text { Singapore, } \\
\text { South } \\
\text { Korea, } \\
\text { and } \\
\text { Taiwan) }\end{array}$ & $\begin{array}{l}\text { Quantitative } \\
\text { (Cross- } \\
\text { sectional } \\
\text { study, } \\
\text { prospec- } \\
\text { tive, } \\
\text { observa- } \\
\text { tional } \\
\text { study) }\end{array}$ & Inpatient & 430 & & $\begin{array}{l}\text { The } \\
\text { purpose to } \\
\text { describe } \\
\text { pharmaco- } \\
\text { logical } \\
\text { treatment } \\
\text { patterns } \\
\text { in patients } \\
\text { with } \\
\text { MDD. }\end{array}$ & $\begin{array}{l}\text { Medication } \\
\text { adherence, } \\
\text { reasons for } \\
\text { medica- } \\
\text { tion } \\
\text { nonadher- } \\
\text { ence, } \\
\text { depressive } \\
\text { symp- } \\
\text { toms, } \\
\text { somatic } \\
\text { symptom, } \\
\text { and } \\
\text { quality of } \\
\text { life }\end{array}$ \\
\hline
\end{tabular}




\begin{tabular}{|c|c|c|c|c|c|c|c|}
\hline $\begin{array}{l}\text { Author } \\
\text { (year) }\end{array}$ & Country & $\begin{array}{l}\text { Study } \\
\text { design }\end{array}$ & $\begin{array}{l}\text { Study } \\
\text { setting }\end{array}$ & $\begin{array}{l}\text { Sample } \\
\text { (Participant } \\
\text { no. (Inter- } \\
\text { ventional, } \\
\text { Control) } \\
\text { Patient } \\
\text { characteris- } \\
\text { tics (age, } \\
\text { gender)) }\end{array}$ & $\begin{array}{l}\text { Sample } \\
\text { (Participant } \\
\text { no. (Inter- } \\
\text { ventional, } \\
\text { Control) } \\
\text { Patient } \\
\text { characteris- } \\
\text { tics (age, } \\
\text { gender)) }\end{array}$ & $\begin{array}{l}\text { Purpose of } \\
\text { study }\end{array}$ & $\begin{array}{l}\text { Outcome } \\
\text { variables }\end{array}$ \\
\hline $\begin{array}{l}\text { Serrano et } \\
\text { al. } \\
(2014)^{59}\end{array}$ & Spain & $\begin{array}{l}\text { Quantitative } \\
\text { (Observa- } \\
\text { tional and } \\
\text { longitudi- } \\
\text { nal } \\
\text { study) }\end{array}$ & Outpatient & 29 & & $\begin{array}{l}\text { The } \\
\text { purpose to } \\
\text { determine } \\
\text { the degree } \\
\text { of thera- } \\
\text { peutic } \\
\text { adherence } \\
\text { in patients } \\
\text { with de- } \\
\text { pression, } \\
\text { examine } \\
\text { factors } \\
\text { involved } \\
\text { in the } \\
\text { adherence } \\
\text { process, } \\
\text { and } \\
\text { observe } \\
\text { the } \\
\text { clinical } \\
\text { outcome. }\end{array}$ & $\begin{array}{l}\text { Medication } \\
\text { adherence, } \\
\text { depressive } \\
\text { symp- } \\
\text { toms, } \\
\text { drug } \\
\text { attitude, } \\
\text { beliefs } \\
\text { about } \\
\text { medica- } \\
\text { tion, and } \\
\text { personality }\end{array}$ \\
\hline $\begin{array}{l}\text { Shrestha } \\
\text { Manand- } \\
\text { har et al. } \\
(2017)^{60}\end{array}$ & Nepal & $\begin{array}{l}\text { Quantitative } \\
\text { (Prospec- } \\
\text { tive } \\
\text { study) }\end{array}$ & $\begin{array}{l}\text { Inpatient } \\
\text { and } \\
\text { outpatient }\end{array}$ & 60 & & $\begin{array}{l}\text { The } \\
\text { purpose to } \\
\text { determine } \\
\text { the medi- } \\
\text { cation } \\
\text { adherence } \\
\text { pattern in } \\
\text { patients } \\
\text { with } \\
\text { depression } \\
\text { and assess } \\
\text { the factors } \\
\text { associated } \\
\text { with non- } \\
\text { adherence } \\
\text { to the } \\
\text { prescribed } \\
\text { antide- } \\
\text { pressant } \\
\text { therapy. }\end{array}$ & $\begin{array}{l}\text { Medication } \\
\text { adherence } \\
\text { and medi- } \\
\text { cation } \\
\text { adherence } \\
\text { pattern }\end{array}$ \\
\hline
\end{tabular}




\begin{tabular}{|c|c|c|c|c|c|c|c|}
\hline $\begin{array}{l}\text { Author } \\
\text { (year) }\end{array}$ & Country & $\begin{array}{l}\text { Study } \\
\text { design }\end{array}$ & $\begin{array}{l}\text { Study } \\
\text { setting }\end{array}$ & $\begin{array}{l}\text { Sample } \\
\text { (Participant } \\
\text { no. (Inter- } \\
\text { ventional, } \\
\text { Control) } \\
\text { Patient } \\
\text { characteris- } \\
\text { tics (age, } \\
\text { gender)) }\end{array}$ & $\begin{array}{l}\text { Sample } \\
\text { (Participant } \\
\text { no. (Inter- } \\
\text { ventional, } \\
\text { Control) } \\
\text { Patient } \\
\text { characteris- } \\
\text { tics (age, } \\
\text { gender)) }\end{array}$ & $\begin{array}{l}\text { Purpose of } \\
\text { study }\end{array}$ & $\begin{array}{l}\text { Outcome } \\
\text { variables }\end{array}$ \\
\hline $\begin{array}{l}\text { Taleban et } \\
\text { al. } \\
(2016)^{61}\end{array}$ & 更 & $\begin{array}{l}\text { Quantitative } \\
\text { (Random- } \\
\text { ized } \\
\text { clinical } \\
\text { trial) }\end{array}$ & Outpatient & 198 & $\begin{array}{l}\text { Booklet } \\
\text { and text } \\
\text { messaging } \\
\text { group } \\
(67), \\
\text { booklet } \\
(66), \text { and } \\
\text { control } \\
(65)\end{array}$ & $\begin{array}{l}\text { The } \\
\text { purpose to } \\
\text { evaluate } \\
\text { the } \\
\text { impacts of } \\
\text { text } \\
\text { messaging } \\
\text { interven- } \\
\text { tions, } \\
\text { which } \\
\text { aimed to } \\
\text { inspire the } \\
\text { affected } \\
\text { patients to } \\
\text { peruse } \\
\text { bibliotherapy. }\end{array}$ & $\begin{array}{l}\text { Medication } \\
\text { adherence } \\
\text { and } \\
\text { depression } \\
\text { severity }\end{array}$ \\
\hline $\begin{array}{l}\text { Vannachavee } \\
\text { et al. } \\
(2016)^{62}\end{array}$ & Thailand & $\begin{array}{l}\text { Quantitative } \\
\text { (Random- } \\
\text { ized } \\
\text { controlled } \\
\text { trial with } \\
\text { two } \\
\text { parallel- } \\
\text { group } \\
\text { posttest- } \\
\text { only } \\
\text { designs) }\end{array}$ & Outpatient & 56 & $(30,26)$ & $\begin{array}{l}\text { The } \\
\text { purpose to } \\
\text { examine } \\
\text { the effect } \\
\text { of DAEP } \\
\text { on } \\
\text { adherence } \\
\text { behaviors } \\
\text { in patients } \\
\text { with first } \\
\text { diagnosed } \\
\text { major } \\
\text { depressive } \\
\text { disorder. }\end{array}$ & $\begin{array}{l}\text { Medication } \\
\text { adherence } \\
\text { and } \\
\text { depression } \\
\text { severity }\end{array}$ \\
\hline
\end{tabular}




\begin{tabular}{|c|c|c|c|c|c|c|c|}
\hline $\begin{array}{l}\text { Author } \\
\text { (year) }\end{array}$ & Country & $\begin{array}{l}\text { Study } \\
\text { design }\end{array}$ & $\begin{array}{l}\text { Study } \\
\text { setting }\end{array}$ & $\begin{array}{l}\text { Sample } \\
\text { (Participant } \\
\text { no. (Inter- } \\
\text { ventional, } \\
\text { Control) } \\
\text { Patient } \\
\text { characteris- } \\
\text { tics (age, } \\
\text { gender)) }\end{array}$ & $\begin{array}{l}\text { Sample } \\
\text { (Participant } \\
\text { no. (Inter- } \\
\text { ventional, } \\
\text { Control) } \\
\text { Patient } \\
\text { characteris- } \\
\text { tics (age, } \\
\text { gender)) }\end{array}$ & $\begin{array}{l}\text { Purpose of } \\
\text { study }\end{array}$ & $\begin{array}{l}\text { Outcome } \\
\text { variables }\end{array}$ \\
\hline $\begin{array}{l}\text { Bushnell } \\
\text { et al. } \\
(2016)^{63}\end{array}$ & USA & $\begin{array}{l}\text { Quantitative } \\
\text { (Retro- } \\
\text { spective } \\
\text { cohort } \\
\text { study) }\end{array}$ & $\begin{array}{l}\text { Inpatient } \\
\text { and } \\
\text { outpatient }\end{array}$ & 8,837 & & $\begin{array}{l}\text { The } \\
\text { purpose to } \\
\text { identify } \\
\text { predictors } \\
\text { of } \\
\text { six-month } \\
\text { antide- } \\
\text { pressant } \\
\text { persistence. }\end{array}$ & $\begin{array}{l}\text { Antidepressan } \\
\text { persis- } \\
\text { tence, } \\
\text { demo- } \\
\text { graphic, } \\
\text { clinical, } \\
\text { and psy- } \\
\text { chosocial } \\
\text { factors } \\
\text { (age, sex, } \\
\text { psychi- } \\
\text { atric and } \\
\text { non- } \\
\text { psychiatric } \\
\text { co- } \\
\text { morbidities, } \\
\text { healthcare } \\
\text { utiliza- } \\
\text { tion, } \\
\text { antide- } \\
\text { pressant } \\
\text { class, } \\
\text { prior } \\
\text { suicide } \\
\text { attempt, } \\
\text { high and } \\
\text { mid- } \\
\text { potency } \\
\text { prescrip- } \\
\text { tion opiate } \\
\text { usage, and } \\
\text { recurrent } \\
\text { MDD } \\
\text { diagnosis) }\end{array}$ \\
\hline
\end{tabular}




\begin{tabular}{|c|c|c|c|c|c|c|c|}
\hline $\begin{array}{l}\text { Author } \\
\text { (year) }\end{array}$ & Country & $\begin{array}{l}\text { Study } \\
\text { design }\end{array}$ & $\begin{array}{l}\text { Study } \\
\text { setting }\end{array}$ & $\begin{array}{l}\text { Sample } \\
\text { (Participant } \\
\text { no. (Inter- } \\
\text { ventional, } \\
\text { Control) } \\
\text { Patient } \\
\text { characteris- } \\
\text { tics (age, } \\
\text { gender)) }\end{array}$ & $\begin{array}{l}\text { Sample } \\
\text { (Participant } \\
\text { no. (Inter- } \\
\text { ventional, } \\
\text { Control) } \\
\text { Patient } \\
\text { characteris- } \\
\text { tics (age, } \\
\text { gender)) }\end{array}$ & $\begin{array}{l}\text { Purpose of } \\
\text { study }\end{array}$ & $\begin{array}{l}\text { Outcome } \\
\text { variables }\end{array}$ \\
\hline $\begin{array}{l}\text { Green et } \\
\text { al. } \\
(2017)^{64}\end{array}$ & USA & $\begin{array}{l}\text { Mixed- } \\
\text { method }\end{array}$ & Outpatient & 28 & & $\begin{array}{l}\text { The } \\
\text { purpose to } \\
\text { investigate } \\
\text { knowledge } \\
\text { and } \\
\text { attitudes } \\
\text { about } \\
\text { antide- } \\
\text { pressant } \\
\text { medica- } \\
\text { tion, } \\
\text { including } \\
\text { risks and } \\
\text { benefits, } \\
\text { how } \\
\text { patients } \\
\text { received } \\
\text { this infor- } \\
\text { mation, } \\
\text { and how } \\
\text { they } \\
\text { would } \\
\text { prefer to } \\
\text { learn } \\
\text { about } \\
\text { antidepressants }\end{array}$ & $\begin{array}{l}\text { Medication } \\
\text { persis- } \\
\text { tence, } \\
\text { knowledge } \\
\text { and } \\
\text { attitudes } \\
\text { about } \\
\text { antide- } \\
\text { pressant } \\
\text { medica- } \\
\text { tion, } \\
\text { Depres- } \\
\text { sion, } \\
\text { Trauma } \\
\text { exposure, } \\
\text { post- } \\
\text { traumatic } \\
\text { stress } \\
\text { disorder, } \\
\text { and side } \\
\text { effects }\end{array}$ \\
\hline $\begin{array}{l}\text { Grover et } \\
\text { al. } \\
(2018)^{65}\end{array}$ & India & $\begin{array}{l}\text { Quantitative } \\
\text { (Natural- } \\
\text { istic, } \\
\text { longitudi- } \\
\text { nal, } \\
\text { follow-up } \\
\text { study) }\end{array}$ & Outpatient & 140 & & $\begin{array}{l}\text { The } \\
\text { purpose to } \\
\text { evaluate } \\
\text { the medi- } \\
\text { cation } \\
\text { adherence, } \\
\text { treatment } \\
\text { adherence, } \\
\text { and } \\
\text { outcome of } \\
\text { depression. }\end{array}$ & $\begin{array}{l}\text { Medication } \\
\text { adherence, } \\
\text { treatment } \\
\text { adherence, } \\
\text { and } \\
\text { outcome } \\
\text { of } \\
\text { depression }\end{array}$ \\
\hline
\end{tabular}




\begin{tabular}{|c|c|c|c|c|c|c|c|}
\hline $\begin{array}{l}\text { Author } \\
\text { (year) }\end{array}$ & Country & $\begin{array}{l}\text { Study } \\
\text { design }\end{array}$ & $\begin{array}{l}\text { Study } \\
\text { setting }\end{array}$ & $\begin{array}{l}\text { Sample } \\
\text { (Participant } \\
\text { no. (Inter- } \\
\text { ventional, } \\
\text { Control) } \\
\text { Patient } \\
\text { characteris- } \\
\text { tics (age, } \\
\text { gender)) }\end{array}$ & $\begin{array}{l}\text { Sample } \\
\text { (Participant } \\
\text { no. (Inter- } \\
\text { ventional, } \\
\text { Control) } \\
\text { Patient } \\
\text { characteris- } \\
\text { tics (age, } \\
\text { gender)) }\end{array}$ & $\begin{array}{l}\text { Purpose of } \\
\text { study }\end{array}$ & $\begin{array}{l}\text { Outcome } \\
\text { variables }\end{array}$ \\
\hline $\begin{array}{l}\text { Holvast et } \\
\text { al. } \\
(2019)^{66}\end{array}$ & Netherlands & $\begin{array}{l}\text { Quantitative } \\
\text { (Longitu- } \\
\text { dinal } \\
\text { study) }\end{array}$ & Outpatient & 1,512 & & $\begin{array}{l}\text { The } \\
\text { purpose to } \\
\text { determine } \\
\text { the non- } \\
\text { adherence } \\
\text { rates to } \\
\text { antide- } \\
\text { pressants } \\
\text { among } \\
\text { older } \\
\text { adults in } \\
\text { primary } \\
\text { care, } \\
\text { based on } \\
\text { non- } \\
\text { initiation, } \\
\text { subopti- } \\
\text { mal } \\
\text { implemen- } \\
\text { tation or } \\
\text { non- } \\
\text { persistence. }\end{array}$ & $\begin{array}{l}\text { Non- } \\
\text { initiation, } \\
\text { subopti- } \\
\text { mal } \\
\text { implemen- } \\
\text { tation, } \\
\text { non- } \\
\text { persistence, } \\
\text { associated } \\
\text { with non- } \\
\text { adherence }\end{array}$ \\
\hline $\begin{array}{l}\text { Klang et } \\
\text { al. } \\
(2015)^{67}\end{array}$ & Israel & $\begin{array}{l}\text { Quantitative } \\
\text { (Prospec- } \\
\text { tive, } \\
\text { nonran- } \\
\text { domized, } \\
\text { open- } \\
\text { label, } \\
\text { naturalis- } \\
\text { tic } \\
\text { observa- } \\
\text { tional } \\
\text { study) }\end{array}$ & Outpatient & 4246 & $\begin{array}{l}(173, \\
4079)\end{array}$ & $\begin{array}{l}\text { The } \\
\text { purpose to } \\
\text { effective- } \\
\text { ness of CP } \\
\text { interven- } \\
\text { tion for } \\
\text { patients } \\
\text { with } \\
\text { MDD. }\end{array}$ & $\begin{array}{l}\text { Medication } \\
\text { adherence } \\
\text { and } \\
\text { depressive } \\
\text { symptoms }\end{array}$ \\
\hline
\end{tabular}




\begin{tabular}{|c|c|c|c|c|c|c|c|}
\hline $\begin{array}{l}\text { Author } \\
\text { (year) }\end{array}$ & Country & $\begin{array}{l}\text { Study } \\
\text { design }\end{array}$ & $\begin{array}{l}\text { Study } \\
\text { setting }\end{array}$ & $\begin{array}{l}\text { Sample } \\
\text { (Participant } \\
\text { no. (Inter- } \\
\text { ventional, } \\
\text { Control) } \\
\text { Patient } \\
\text { characteris- } \\
\text { tics (age, } \\
\text { gender)) }\end{array}$ & $\begin{array}{l}\text { Sample } \\
\text { (Participant } \\
\text { no. (Inter- } \\
\text { ventional, } \\
\text { Control) } \\
\text { Patient } \\
\text { characteris- } \\
\text { tics (age, } \\
\text { gender)) }\end{array}$ & $\begin{array}{l}\text { Purpose of } \\
\text { study }\end{array}$ & $\begin{array}{l}\text { Outcome } \\
\text { variables }\end{array}$ \\
\hline $\begin{array}{l}\text { LeBlanc et } \\
\text { al. }(2015)^{68}\end{array}$ & USA & $\begin{array}{l}\text { Quantitative } \\
\text { (Cluster } \\
\text { randomized } \\
\text { trial) }\end{array}$ & Outpatient & $\begin{array}{l}\text { Clinicians } \\
(117) ; \\
\text { patients } \\
(297)\end{array}$ & $\begin{array}{l}\text { Clinicians } \\
(66,51) ; \\
\text { patients } \\
(158,139)\end{array}$ & $\begin{array}{l}\text { The purpose } \\
\text { to estimate } \\
\text { the effect of } \\
\text { DMC on } \\
\text { quality of } \\
\text { the decision- } \\
\text { making } \\
\text { process and } \\
\text { depression } \\
\text { outcomes. }\end{array}$ & $\begin{array}{l}\text { Patient } \\
\text { knowledge } \\
\text { and } \\
\text { involvement } \\
\text { in decision } \\
\text { making, } \\
\text { patient and } \\
\text { clinician } \\
\text { decisional } \\
\text { comfort and } \\
\text { satisfaction, } \\
\text { encounter } \\
\text { duration, } \\
\text { medication } \\
\text { adherence, } \\
\text { and } \\
\text { depression } \\
\text { symptoms }\end{array}$ \\
\hline $\begin{array}{l}\text { Slabbert } \\
\text { et al. } \\
(2015)^{69}\end{array}$ & $\begin{array}{l}\text { South } \\
\text { Africa }\end{array}$ & $\begin{array}{l}\text { Quantitative } \\
\text { (Prospec- } \\
\text { tive, } \\
\text { descriptive } \\
\text { cohort } \\
\text { study) }\end{array}$ & Outpatient & 14,135 & & $\begin{array}{l}\text { The } \\
\text { purpose to } \\
\text { investigate } \\
\text { the } \\
\text { prevalence } \\
\text { of antide- } \\
\text { pressant } \\
\text { non- } \\
\text { compliance } \\
\text { in the } \\
\text { private } \\
\text { healthcare } \\
\text { sector of } \\
\text { South } \\
\text { Africa. }\end{array}$ & $\begin{array}{l}\text { Medication } \\
\text { adherence }\end{array}$ \\
\hline
\end{tabular}




\begin{tabular}{|c|c|c|c|c|c|c|c|}
\hline $\begin{array}{l}\text { Author } \\
\text { (year) }\end{array}$ & Country & $\begin{array}{l}\text { Study } \\
\text { design }\end{array}$ & $\begin{array}{l}\text { Study } \\
\text { setting }\end{array}$ & $\begin{array}{l}\text { Sample } \\
\text { (Participant } \\
\text { no. (Inter- } \\
\text { ventional, } \\
\text { Control) } \\
\text { Patient } \\
\text { characteris- } \\
\text { tics (age, } \\
\text { gender)) }\end{array}$ & $\begin{array}{l}\text { Sample } \\
\text { (Participant } \\
\text { no. (Inter- } \\
\text { ventional, } \\
\text { Control) } \\
\text { Patient } \\
\text { characteris- } \\
\text { tics (age, } \\
\text { gender)) }\end{array}$ & $\begin{array}{l}\text { Purpose of } \\
\text { study }\end{array}$ & $\begin{array}{l}\text { Outcome } \\
\text { variables }\end{array}$ \\
\hline $\begin{array}{l}\text { Zhang et } \\
\text { al. } \\
(2016)^{70}\end{array}$ & China & $\begin{array}{l}\text { Quantitative } \\
\text { (Retro- } \\
\text { spective } \\
\text { cohort } \\
\text { study) }\end{array}$ & $\begin{array}{l}\text { Inpatient } \\
\text { and } \\
\text { outpatient }\end{array}$ & 8,484 & & $\begin{array}{l}\text { The } \\
\text { purpose to } \\
\text { investigate } \\
\text { medica- } \\
\text { tion usage } \\
\text { patterns, } \\
\text { health } \\
\text { care } \\
\text { resource } \\
\text { utiliza- } \\
\text { tion, and } \\
\text { direct } \\
\text { medical } \\
\text { costs of } \\
\text { patients } \\
\text { with MDD } \\
\text { in Beijing, } \\
\text { People's } \\
\text { Republic } \\
\text { of China. }\end{array}$ & $\begin{array}{l}\text { Medication } \\
\text { usage } \\
\text { patterns, } \\
\text { health } \\
\text { care } \\
\text { resource } \\
\text { utiliza- } \\
\text { tion, and } \\
\text { economic } \\
\text { burden }\end{array}$ \\
\hline $\begin{array}{l}\text { Hammonds } \\
\text { et al. } \\
(2015)^{71}\end{array}$ & USA & $\begin{array}{l}\text { Quantitative } \\
\text { (Random- } \\
\text { ized, } \\
\text { parallel- } \\
\text { group } \\
\text { clinical } \\
\text { trial) }\end{array}$ & Outpatient & 57 & $(30,27)$ & $\begin{array}{l}\text { The } \\
\text { purpose to } \\
\text { determine } \\
\text { the effect } \\
\text { of medica- } \\
\text { tion } \\
\text { reminding } \\
\text { via smart- } \\
\text { phone app } \\
\text { on } \\
\text { adherence } \\
\text { to antide- } \\
\text { pressant } \\
\text { medica- } \\
\text { tions in } \\
\text { college } \\
\text { students. }\end{array}$ & $\begin{array}{l}\text { Medication } \\
\text { adherence, } \\
\text { depres- } \\
\text { sion, } \\
\text { social } \\
\text { support, } \\
\text { stress, and } \\
\text { health } \\
\text { beliefs }\end{array}$ \\
\hline
\end{tabular}




\begin{tabular}{|c|c|c|c|c|c|c|c|}
\hline $\begin{array}{l}\text { Author } \\
\text { (year) }\end{array}$ & Country & $\begin{array}{l}\text { Study } \\
\text { design }\end{array}$ & $\begin{array}{l}\text { Study } \\
\text { setting }\end{array}$ & $\begin{array}{l}\text { Sample } \\
\text { (Participant } \\
\text { no. (Inter- } \\
\text { ventional, } \\
\text { Control) } \\
\text { Patient } \\
\text { characteris- } \\
\text { tics (age, } \\
\text { gender)) }\end{array}$ & $\begin{array}{l}\text { Sample } \\
\text { (Participant } \\
\text { no. (Inter- } \\
\text { ventional, } \\
\text { Control) } \\
\text { Patient } \\
\text { characteris- } \\
\text { tics (age, } \\
\text { gender)) }\end{array}$ & $\begin{array}{l}\text { Purpose of } \\
\text { study }\end{array}$ & $\begin{array}{l}\text { Outcome } \\
\text { variables }\end{array}$ \\
\hline $\begin{array}{l}\text { Pradeep } \\
\text { et al. } \\
(2014)^{72}\end{array}$ & India & $\begin{array}{l}\text { Quantitative } \\
\text { (Random- } \\
\text { ized } \\
\text { trial) }\end{array}$ & Outpatient & 260 & $(122,138)$ & $\begin{array}{l}\text { The } \\
\text { purpose to } \\
\text { investigate } \\
\text { effective- } \\
\text { ness of } \\
\text { enhanced } \\
\text { care in } \\
\text { improving } \\
\text { treatment } \\
\text { seeking } \\
\text { and } \\
\text { adherence } \\
\text { to antide- } \\
\text { pressant } \\
\text { medica- } \\
\text { tion in } \\
\text { women } \\
\text { with } \\
\text { depression } \\
\text { living in } \\
\text { rural } \\
\text { India. }\end{array}$ & $\begin{array}{l}\text { Medication } \\
\text { adherence, } \\
\text { number of } \\
\text { clinic } \\
\text { visits, } \\
\text { depressive } \\
\text { symp- } \\
\text { toms, and } \\
\text { quality of } \\
\text { life }\end{array}$ \\
\hline
\end{tabular}




\begin{tabular}{|c|c|c|c|c|c|c|c|}
\hline $\begin{array}{l}\text { Author } \\
\text { (year) }\end{array}$ & Country & $\begin{array}{l}\text { Study } \\
\text { design }\end{array}$ & $\begin{array}{l}\text { Study } \\
\text { setting }\end{array}$ & $\begin{array}{l}\text { Sample } \\
\text { (Participant } \\
\text { no. (Inter- } \\
\text { ventional, } \\
\text { Control) } \\
\text { Patient } \\
\text { characteris- } \\
\text { tics (age, } \\
\text { gender)) }\end{array}$ & $\begin{array}{l}\text { Sample } \\
\text { (Participant } \\
\text { no. (Inter- } \\
\text { ventional, } \\
\text { Control) } \\
\text { Patient } \\
\text { characteris- } \\
\text { tics (age, } \\
\text { gender)) }\end{array}$ & $\begin{array}{l}\text { Purpose of } \\
\text { study }\end{array}$ & $\begin{array}{l}\text { Outcome } \\
\text { variables }\end{array}$ \\
\hline $\begin{array}{l}\text { Srimongkon } \\
\text { et al. } \\
(2018)^{73}\end{array}$ & Australia & $\begin{array}{l}\text { Qualitative } \\
\text { (Phe- } \\
\text { nomeno- } \\
\text { logical } \\
\text { approach) }\end{array}$ & Outpatient & 23 & & $\begin{array}{l}\text { The } \\
\text { purpose to } \\
\text { explore } \\
\text { factors } \\
\text { which } \\
\text { facilitate } \\
\text { and } \\
\text { negatively } \\
\text { impact } \\
\text { adherence, } \\
\text { at } \\
\text { initiation, } \\
\text { implemen- } \\
\text { tation and } \\
\text { discontin- } \\
\text { uation } \\
\text { phases of } \\
\text { adherence } \\
\text { to antide- } \\
\text { pressant } \\
\text { medication. }\end{array}$ & $\begin{array}{l}\text { Facilitate } \\
\text { and } \\
\text { negatively } \\
\text { impact } \\
\text { adherence }\end{array}$ \\
\hline
\end{tabular}




\begin{tabular}{|c|c|c|c|c|c|c|c|}
\hline $\begin{array}{l}\text { Author } \\
\text { (year) }\end{array}$ & Country & $\begin{array}{l}\text { Study } \\
\text { design }\end{array}$ & $\begin{array}{l}\text { Study } \\
\text { setting }\end{array}$ & $\begin{array}{l}\text { Sample } \\
\text { (Participant } \\
\text { no. (Inter- } \\
\text { ventional, } \\
\text { Control) } \\
\text { Patient } \\
\text { characteris- } \\
\text { tics (age, } \\
\text { gender)) }\end{array}$ & $\begin{array}{l}\text { Sample } \\
\text { (Participant } \\
\text { no. (Inter- } \\
\text { ventional, } \\
\text { Control) } \\
\text { Patient } \\
\text { characteris- } \\
\text { tics (age, } \\
\text { gender)) }\end{array}$ & $\begin{array}{l}\text { Purpose of } \\
\text { study }\end{array}$ & $\begin{array}{l}\text { Outcome } \\
\text { variables }\end{array}$ \\
\hline $\begin{array}{l}\text { Vargas et } \\
\text { al. } \\
(2015)^{74}\end{array}$ & USA & $\begin{array}{l}\text { Qualitative } \\
\text { (Ethnography) }\end{array}$ & Outpatient & 30 & & $\begin{array}{l}\text { The } \\
\text { purpose to } \\
\text { examines } \\
\text { salient } \\
\text { views of } \\
\text { depression } \\
\text { and } \\
\text { pharma- } \\
\text { cotherapy } \\
\text { among } \\
\text { Latinos } \\
\text { seeking } \\
\text { outpatient } \\
\text { antide- } \\
\text { pressant } \\
\text { therapy } \\
\text { and } \\
\text { suggests } \\
\text { possible } \\
\text { strategies } \\
\text { for } \\
\text { engaging } \\
\text { patients } \\
\text { on these } \\
\text { views } \\
\text { prior to } \\
\text { the onset } \\
\text { of } \\
\text { treatment. }\end{array}$ & $\begin{array}{l}\text { Views of } \\
\text { depression } \\
\text { and } \\
\text { antide- } \\
\text { pressant } \\
\text { medication }\end{array}$ \\
\hline
\end{tabular}

**Note: CBT: Cognitive Behavioural Therapy; CP: Community pharmacist; DAEP: Drug Adherence Enhancement Program; DMC: Depression Medication Choice; MDD: Major Depressive Disorder; SDM: Shared Based on Decision Making; TIP: The Treatment Initiation and Participation

Table 2 . Quality of Studies by Mixed Methods Appraisal Tool (MMAT) (n = 36) 


\begin{tabular}{|c|c|c|c|c|c|c|}
\hline $\begin{array}{l}\text { Qualitative } \\
\text { Studies }\end{array}$ & $\begin{array}{l}\text { Qualitative } \\
\text { Studies }\end{array}$ & $\begin{array}{l}\text { Qualitative } \\
\text { Studies }\end{array}$ & $\begin{array}{l}\text { Qualitative } \\
\text { Studies }\end{array}$ & $\begin{array}{l}\text { Qualitative } \\
\text { Studies }\end{array}$ & $\begin{array}{l}\text { Qualitative } \\
\text { Studies }\end{array}$ & $\begin{array}{l}\text { Qualitative } \\
\text { Studies }\end{array}$ \\
\hline $\begin{array}{l}\text { Criteria } \\
\text { Author } \\
\text { (year) }\end{array}$ & $\begin{array}{l}\text { Is the } \\
\text { qualitative } \\
\text { approach } \\
\text { appropriate to } \\
\text { answer the } \\
\text { research } \\
\text { question? }\end{array}$ & $\begin{array}{l}\text { Are the } \\
\text { qualitative } \\
\text { data collection } \\
\text { methods } \\
\text { adequate to } \\
\text { address the } \\
\text { research } \\
\text { question? }\end{array}$ & $\begin{array}{l}\text { Are the } \\
\text { findings } \\
\text { adequately } \\
\text { derived from } \\
\text { the data? }\end{array}$ & $\begin{array}{l}\text { Is the } \\
\text { interpretation } \\
\text { of results } \\
\text { sufficiently } \\
\text { substantiated } \\
\text { by data? }\end{array}$ & $\begin{array}{l}\text { Is there } \\
\text { coherence } \\
\text { between } \\
\text { qualitative } \\
\text { data sources, } \\
\text { collection, } \\
\text { analysis and } \\
\text { interpretation? }\end{array}$ & $\begin{array}{l}\text { MMAT } \\
\text { score }\end{array}$ \\
\hline $\begin{array}{l}\text { Ho et al. } \\
(2017)^{24}\end{array}$ & & & & & & 100 \\
\hline $\begin{array}{l}\text { Srimongkon } \\
\text { et al. } \\
(2018)^{73}\end{array}$ & & & & & & 100 \\
\hline $\begin{array}{l}\text { Vargas et al. } \\
(2015)^{74}\end{array}$ & & & & & & 100 \\
\hline Quantitative & Quantitative & Quantitative & Quantitative & Quantitative & Quantitative & Quantitative \\
\hline $\begin{array}{l}\text { Random- } \\
\text { ized }\end{array}$ & $\begin{array}{l}\text { Random- } \\
\text { ized }\end{array}$ & $\begin{array}{l}\text { Random- } \\
\text { ized }\end{array}$ & $\begin{array}{l}\text { Random- } \\
\text { ized }\end{array}$ & $\begin{array}{l}\text { Random- } \\
\text { ized }\end{array}$ & $\begin{array}{l}\text { Random- } \\
\text { ized }\end{array}$ & $\begin{array}{l}\text { Random- } \\
\text { ized }\end{array}$ \\
\hline Controlled & Controlled & Controlled & Controlled & Controlled & Controlled & Controlled \\
\hline Trials & Trials & Trials & Trials & Trials & Trials & Trials \\
\hline $\begin{array}{l}\text { Criteria } \\
\text { Author } \\
\text { (year) }\end{array}$ & $\begin{array}{l}\text { Is } \\
\text { randomization } \\
\text { appropriately } \\
\text { performed? }\end{array}$ & $\begin{array}{l}\text { Are the groups } \\
\text { comparable at } \\
\text { baseline? }\end{array}$ & $\begin{array}{l}\text { Are there } \\
\text { complete } \\
\text { outcome data } \\
\text { ( } 80 \% \text { or } \\
\text { above)? }\end{array}$ & $\begin{array}{l}\text { Are outcome } \\
\text { assessors } \\
\text { blinded to the } \\
\text { intervention } \\
\text { provided? }\end{array}$ & $\begin{array}{l}\text { Did the } \\
\text { participants } \\
\text { adhere to the } \\
\text { assigned } \\
\text { intervention } \\
\text { ( } 80 \% \text { or } \\
\text { above)? }\end{array}$ & $\begin{array}{l}\text { MMAT } \\
\text { score }\end{array}$ \\
\hline $\begin{array}{l}\text { Sirey et al. } \\
(2017)^{19}\end{array}$ & & & & & & 100 \\
\hline $\begin{array}{l}\text { Aljumah \& } \\
\text { Hassali } \\
(2015)^{47}\end{array}$ & & & & & & 100 \\
\hline $\begin{array}{l}\text { Taleban et } \\
\text { al. }(2016)^{61}\end{array}$ & & & & $\mathrm{x}$ & & 75 \\
\hline $\begin{array}{l}\text { Vannachavee } \\
\text { et al. } \\
(2016)^{62}\end{array}$ & & & & $\mathrm{x}$ & & 75 \\
\hline $\begin{array}{l}\text { LeBlanc et } \\
\text { al. }(2015)^{68}\end{array}$ & & & & $\mathrm{x}$ & & 75 \\
\hline $\begin{array}{l}\text { Hammonds } \\
\text { et al. } \\
(2015)^{71}\end{array}$ & & & & $\mathrm{x}$ & & 75 \\
\hline $\begin{array}{l}\text { Pradeep et } \\
\text { al. }(2014)^{72}\end{array}$ & & & & & & 100 \\
\hline Quantitative & Quantitative & Quantitative & Quantitative & Quantitative & Quantitative & Quantitative \\
\hline Non- & Non- & Non- & Non- & Non- & Non- & Non- \\
\hline Randomized & Randomized & Randomized & Randomized & Randomized & Randomized & Randomized \\
\hline
\end{tabular}




\begin{tabular}{|c|c|c|c|c|c|c|}
\hline $\begin{array}{l}\text { Qualitative } \\
\text { Studies }\end{array}$ & $\begin{array}{l}\text { Qualitative } \\
\text { Studies }\end{array}$ & $\begin{array}{l}\text { Qualitative } \\
\text { Studies }\end{array}$ & $\begin{array}{l}\text { Qualitative } \\
\text { Studies }\end{array}$ & $\begin{array}{l}\text { Qualitative } \\
\text { Studies }\end{array}$ & $\begin{array}{l}\text { Qualitative } \\
\text { Studies }\end{array}$ & $\begin{array}{l}\text { Qualitative } \\
\text { Studies }\end{array}$ \\
\hline $\begin{array}{l}\text { Criteria } \\
\text { Author } \\
\text { (year) }\end{array}$ & $\begin{array}{l}\text { Are the } \\
\text { participants } \\
\text { representative } \\
\text { of the target } \\
\text { population? }\end{array}$ & $\begin{array}{l}\text { Are } \\
\text { measurements } \\
\text { appropriate } \\
\text { regarding both } \\
\text { the outcome } \\
\text { and } \\
\text { intervention } \\
\text { (or exposure)? }\end{array}$ & $\begin{array}{l}\text { Are there } \\
\text { complete } \\
\text { outcome data? }\end{array}$ & $\begin{array}{l}\text { Are the } \\
\text { confounders } \\
\text { accounted for } \\
\text { in the design } \\
\text { and analysis? }\end{array}$ & $\begin{array}{l}\text { During the } \\
\text { study period, } \\
\text { is the } \\
\text { intervention } \\
\text { administered } \\
\text { (or exposure } \\
\text { occurred) as } \\
\text { intended? }\end{array}$ & $\begin{array}{l}\text { MMAT } \\
\text { score }\end{array}$ \\
\hline $\begin{array}{l}\text { Bhat et al. } \\
(2018)^{49}\end{array}$ & & & & & & 100 \\
\hline $\begin{array}{l}\text { Isa et al. } \\
(2018)^{54}\end{array}$ & & & & $x$ & & 75 \\
\hline $\begin{array}{l}\text { Klang et al. } \\
(2015)^{67}\end{array}$ & & $\mathrm{x}$ & & $\mathrm{x}$ & & 50 \\
\hline Quantitative & Quantitative & Quantitative & Quantitative & Quantitative & Quantitative & Quantitative \\
\hline $\begin{array}{l}\text { Descrip- } \\
\text { tive }\end{array}$ & $\begin{array}{l}\text { Descrip- } \\
\text { tive }\end{array}$ & $\begin{array}{l}\text { Descrip- } \\
\text { tive }\end{array}$ & $\begin{array}{l}\text { Descrip- } \\
\text { tive }\end{array}$ & $\begin{array}{l}\text { Descrip- } \\
\text { tive }\end{array}$ & $\begin{array}{l}\text { Descrip- } \\
\text { tive }\end{array}$ & $\begin{array}{l}\text { Descrip- } \\
\text { tive }\end{array}$ \\
\hline Studies & Studies & Studies & Studies & Studies & Studies & Studies \\
\hline $\begin{array}{l}\text { Criteria } \\
\text { Author } \\
\text { (year) }\end{array}$ & $\begin{array}{l}\text { Is the } \\
\text { sampling } \\
\text { strategy } \\
\text { relevant to } \\
\text { address the } \\
\text { research } \\
\text { question? }\end{array}$ & $\begin{array}{l}\text { Is the sample } \\
\text { representative } \\
\text { of the target } \\
\text { population? }\end{array}$ & $\begin{array}{l}\text { Are the } \\
\text { measurements } \\
\text { appropriate? }\end{array}$ & $\begin{array}{l}\text { Is the risk of } \\
\text { nonresponse } \\
\text { bias low }(60 \% \\
\text { or above)? }\end{array}$ & $\begin{array}{l}\text { Is the } \\
\text { statistical } \\
\text { analysis } \\
\text { appropriate to } \\
\text { answer the } \\
\text { research } \\
\text { question? }\end{array}$ & $\begin{array}{l}\text { MMAT } \\
\text { score }\end{array}$ \\
\hline $\begin{array}{l}\text { Alekhya et } \\
\text { al. }(2015)^{21}\end{array}$ & & & $\mathrm{x}$ & $\mathrm{x}$ & & 50 \\
\hline $\begin{array}{l}\text { Abegaz et } \\
\text { al. }(2017)^{22}\end{array}$ & & & & & & 100 \\
\hline $\begin{array}{l}\text { Al-Jumah et } \\
\text { al. }(2014)^{23}\end{array}$ & & & & & & 100 \\
\hline $\begin{array}{l}\text { Yau et al. } \\
(2014)^{25}\end{array}$ & & & & & & 100 \\
\hline $\begin{array}{l}\text { Mert et al. } \\
(2015)^{34}\end{array}$ & & & $\mathrm{x}$ & & & 75 \\
\hline $\begin{array}{l}\text { Al-Jumah et } \\
\text { al. }(2014)^{46}\end{array}$ & & & & & & 100 \\
\hline $\begin{array}{l}\text { Baeza- } \\
\text { Velasco et } \\
\text { al. }(2019)^{48}\end{array}$ & & & & & & 100 \\
\hline $\begin{array}{l}\text { Burnett- } \\
\text { Zeigler et al. } \\
(2014)^{50}\end{array}$ & & & & & & 100 \\
\hline $\begin{array}{l}\text { Chatterjee } \\
\text { et al. } \\
(2017)^{51}\end{array}$ & & & & $\mathrm{x}$ & & 75 \\
\hline $\begin{array}{l}\text { De las } \\
\text { Cuevas et al. } \\
(2014)^{52}\end{array}$ & & & & & & 100 \\
\hline
\end{tabular}




\begin{tabular}{|c|c|c|c|c|c|c|}
\hline $\begin{array}{l}\text { Qualitative } \\
\text { Studies }\end{array}$ & $\begin{array}{l}\text { Qualitative } \\
\text { Studies }\end{array}$ & $\begin{array}{l}\text { Qualitative } \\
\text { Studies }\end{array}$ & $\begin{array}{l}\text { Qualitative } \\
\text { Studies }\end{array}$ & $\begin{array}{l}\text { Qualitative } \\
\text { Studies }\end{array}$ & $\begin{array}{l}\text { Qualitative } \\
\text { Studies }\end{array}$ & $\begin{array}{l}\text { Qualitative } \\
\text { Studies }\end{array}$ \\
\hline $\begin{array}{l}\text { De Las } \\
\text { Cuevas et al. } \\
(2014)^{53}\end{array}$ & & & & & & 100 \\
\hline $\begin{array}{l}\text { Klein et al. } \\
(2017)^{55}\end{array}$ & & & & $\mathrm{x}$ & & 75 \\
\hline $\begin{array}{l}\text { Lu et al. } \\
(2016)^{56}\end{array}$ & & & & & & 100 \\
\hline $\begin{array}{l}\text { Lucca et al. } \\
(2015)^{57}\end{array}$ & & & & & & 100 \\
\hline $\begin{array}{l}\text { Novick et al. } \\
(2015)^{58}\end{array}$ & & & $\mathrm{x}$ & & & 75 \\
\hline $\begin{array}{l}\text { Serrano et } \\
\text { al. }(2014)^{59}\end{array}$ & & $\mathrm{x}$ & & $\mathrm{x}$ & & 50 \\
\hline $\begin{array}{l}\text { Shrestha } \\
\text { Manandhar } \\
\text { et al. } \\
(2017)^{60}\end{array}$ & & $\mathrm{x}$ & $\mathrm{x}$ & $\mathrm{x}$ & & 25 \\
\hline $\begin{array}{l}\text { Bushnell et } \\
\text { al. }(2016)^{63}\end{array}$ & & & $\mathrm{x}$ & & & 75 \\
\hline $\begin{array}{l}\text { Grover et al. } \\
(2018)^{65}\end{array}$ & & & $\mathrm{x}$ & $\mathrm{x}$ & & 50 \\
\hline $\begin{array}{l}\text { Holvast et } \\
\text { al. }(2019)^{66}\end{array}$ & & & & $\mathrm{x}$ & & 75 \\
\hline $\begin{array}{l}\text { Slabbert et } \\
\text { al. }(2015)^{69}\end{array}$ & & & & $\mathrm{x}$ & & 75 \\
\hline $\begin{array}{l}\text { Zhang et al. } \\
(2016)^{70}\end{array}$ & & & & & & 100 \\
\hline Mixed & Mixed & Mixed & Mixed & Mixed & Mixed & Mixed \\
\hline Methods & Methods & Methods & Methods & Methods & Methods & Methods \\
\hline Studies & Studies & Studies & Studies & Studies & Studies & Studies \\
\hline $\begin{array}{l}\text { Criteria } \\
\text { Author } \\
\text { (year) }\end{array}$ & $\begin{array}{l}\text { Is there an } \\
\text { adequate } \\
\text { rationale for } \\
\text { using a mixed } \\
\text { methods } \\
\text { design to } \\
\text { address the } \\
\text { research } \\
\text { question? }\end{array}$ & $\begin{array}{l}\text { Are the } \\
\text { different } \\
\text { components of } \\
\text { the study } \\
\text { effectively } \\
\text { integrated to } \\
\text { answer the } \\
\text { research } \\
\text { question? }\end{array}$ & $\begin{array}{l}\text { Are the } \\
\text { outputs of the } \\
\text { integration of } \\
\text { qualitative and } \\
\text { quantitative } \\
\text { components } \\
\text { adequately } \\
\text { interpreted? }\end{array}$ & $\begin{array}{l}\text { Are } \\
\text { divergences } \\
\text { and } \\
\text { inconsistencies } \\
\text { between } \\
\text { quantitative } \\
\text { and qualitative } \\
\text { results } \\
\text { adequately } \\
\text { addressed? }\end{array}$ & $\begin{array}{l}\text { Do the } \\
\text { different } \\
\text { components of } \\
\text { the study } \\
\text { adhere to the } \\
\text { quality criteria } \\
\text { of each } \\
\text { tradition of } \\
\text { the methods } \\
\text { involved? }\end{array}$ & $\begin{array}{l}\text { MMAT } \\
\text { score }\end{array}$ \\
\hline $\begin{array}{l}\text { Green et al. } \\
(2017)^{64}\end{array}$ & & & & & $\mathrm{x}$ & 75 \\
\hline
\end{tabular}

$=$ yes; $\mathrm{x}=\mathrm{no}$; $\mathrm{o}=$ can't tell; MMAT=Mixed Methods Appraisal Tool; All studies go through quality assessment passed the screening questions: 1) Are there clear research questions? 2) Do the collected data allow to address the research questions?

***Notes on study limitations using mixed methods appraisal tool (MMAT) criteria 
Table 3. Study Design and Quality of Included Studies $(\mathrm{n}=36)$

\begin{tabular}{llllll}
\hline Study design & Study no. (\%) & MMAT score & MMAT score & MMAT score & MN \\
\hline & & 0 & 25 & 50 & 75 \\
Qualitative Studies & $3(8.3)$ & - & - & - & - \\
Quantitative Randomized Controlled Trials & $7(19.5)$ & - & - & - & 4 \\
Quantitative Non-Randomized Studies & $3(8.3)$ & - & - & 1 & 1 \\
Quantitative Descriptive Studies & $22(61.1)$ & - & 1 & 3 & 1 \\
Mixed Methods Studies & $1(2.8)$ & - & - & - & $1(2.8)$ \\
Study no. (\%) & Study no. (\%) & - & $4(11.1)$ & 13 \\
\hline
\end{tabular}

Table 4. Medication Adherence Rate and Adherence Measurement Methods of Included Studies ( $\mathrm{n}=33$ )

\begin{tabular}{|c|c|c|c|c|}
\hline Author (year) & $\begin{array}{l}\text { Period of data } \\
\text { collection }\end{array}$ & $\begin{array}{l}\text { Medication } \\
\text { adherence rate } \\
(\mathrm{I}: \mathrm{C})\end{array}$ & $\begin{array}{l}\text { Adherence } \\
\text { measure }\end{array}$ & $\begin{array}{l}\text { Data collection } \\
\text { methods }\end{array}$ \\
\hline $\begin{array}{l}\text { Sirey et al. } \\
(2017)^{19}\end{array}$ & 3 years & $\begin{array}{l}\text { The } 5 \text {-fold } \\
\text { increase in } \\
\text { adherence during } \\
\text { the first } 6 \text { weeks } \\
\text { of care }\end{array}$ & $\mathrm{BMQ}$ & Self-Report \\
\hline $\begin{array}{l}\text { Alekhya et al. } \\
(2015)^{21}\end{array}$ & 6 months & $30.1 \%$ & DAI & Self-Report \\
\hline $\begin{array}{l}\text { Abegaz et al. } \\
(2017)^{22}\end{array}$ & 4 months & $10.6 \%$ & MMAS (8-items) & Self-Report \\
\hline $\begin{array}{l}\text { Al-Jumah et al. } \\
(2014)^{23}\end{array}$ & 5 months & $47.1 \%$ & MMAS (8-items) & Self-Report \\
\hline $\begin{array}{l}\text { Yau et al. } \\
(2014)^{25}\end{array}$ & 1 year & $54 \%$ & $\begin{array}{l}\text { The prescription } \\
\text { record and also } \\
\text { the electronic and } \\
\text { written medical } \\
\text { records (filled } \\
\text { prescriptions for } \\
\text { any } \\
\text { antidepressants } \\
\text { with no gaps of } \\
>15 \text { days within } 6 \\
\text { months after } \\
\text { initiation of } \\
\text { treatment) }\end{array}$ & Claims Database \\
\hline
\end{tabular}




\begin{tabular}{|c|c|c|c|c|}
\hline Author (year) & $\begin{array}{l}\text { Period of data } \\
\text { collection }\end{array}$ & $\begin{array}{l}\text { Medication } \\
\text { adherence rate } \\
\text { (I:C) }\end{array}$ & $\begin{array}{l}\text { Adherence } \\
\text { measure }\end{array}$ & $\begin{array}{l}\text { Data collection } \\
\text { methods }\end{array}$ \\
\hline $\begin{array}{l}\text { Mert et al. } \\
(2015)^{34}\end{array}$ & 1 year & $69.2 \%$ & $\begin{array}{l}\text { Not taking any } \\
\text { medicine for at } \\
\text { least } 1 \text { week } \\
\text { during the } \\
6 \text {-month term } \\
\text { before the study } \\
\text { was regarded as } \\
\text { medication } \\
\text { nonadherence; } \\
\text { from first-degree } \\
\text { relatives and } \\
\text { patient files. }\end{array}$ & $\begin{array}{l}\text { Self-Report and } \\
\text { patient record }\end{array}$ \\
\hline $\begin{array}{l}\text { Al-Jumah et al. } \\
(2014)^{46}\end{array}$ & 5 months & $47.1 \%$ & MMAS (8-items) & Self-Report \\
\hline $\begin{array}{l}\text { Aljumah and } \\
\text { Hassali }(2015)^{47}\end{array}$ & 6 months & $\mathrm{NM}$ & MMAS (8-items) & Self-Report \\
\hline $\begin{array}{l}\text { Baeza-Velasco et } \\
\text { al. }(2019)^{48}\end{array}$ & $\mathrm{NM}$ & $29.7 \%$ & MARS & Self-Report \\
\hline $\begin{array}{l}\text { Bhat et al. } \\
(2018)^{49}\end{array}$ & 5 months & $81 \%$ & $\begin{array}{l}\text { Unstructured } \\
\text { scale contains one } \\
\text { question }\end{array}$ & Self-Report \\
\hline $\begin{array}{l}\text { Burnett-Zeigler et } \\
\text { al. }(2014)^{50}\end{array}$ & 4 months & $\mathrm{NM}$ & BMQ & Self-Report \\
\hline $\begin{array}{l}\text { Chatterjee et al. } \\
(2017)^{51}\end{array}$ & NM & NM & MMAS (8-items) & Self-Report \\
\hline $\begin{array}{l}\text { De las Cuevas et } \\
\text { al. }(2014)^{52}\end{array}$ & 8 months & $53.8 \%$ & MGLS (4-items) & Self-Report \\
\hline $\begin{array}{l}\text { De Las Cuevas et } \\
\text { al. }(2014)^{53}\end{array}$ & 4 months & $49.6 \%$ & MGLS (4-items) & Self-Report \\
\hline Isa et al. $(2018)^{54}$ & 2 months & $\mathrm{NM}$ & $\begin{array}{l}\text { Attitude to } \\
\text { Medication } \\
\text { Adherence } \\
\text { Questionnaire }\end{array}$ & Self-Report \\
\hline $\begin{array}{l}\text { Klein et al. } \\
(2017)^{55}\end{array}$ & $\mathrm{NM}$ & $51.9 \%$ & MGLS (4-items) & Self-Report \\
\hline Lu et al. $(2016)^{56}$ & 9 months & $37.8 \%$ & MGLS (4-items) & Self-Report \\
\hline $\begin{array}{l}\text { Lucca et al. } \\
(2015)^{57}\end{array}$ & 1 year & $58.2 \%$ & MARS & Self-Report \\
\hline
\end{tabular}




\begin{tabular}{|c|c|c|c|c|}
\hline Author (year) & $\begin{array}{l}\text { Period of data } \\
\text { collection }\end{array}$ & $\begin{array}{l}\text { Medication } \\
\text { adherence rate } \\
\text { (I:C) }\end{array}$ & $\begin{array}{l}\text { Adherence } \\
\text { measure }\end{array}$ & $\begin{array}{l}\text { Data collection } \\
\text { methods }\end{array}$ \\
\hline $\begin{array}{l}\text { Novick et al. } \\
(2015)^{58}\end{array}$ & 7 months & $\begin{array}{l}\text { Patient-reported: } \\
42.5 \% \text {; } \\
\text { clinician-reported: } \\
85.4 \%\end{array}$ & $\begin{array}{l}\text {-Clinicians were } \\
\text { asked to provide } \\
\text { their opinion on } \\
\text { whether the patient } \\
\text { had been adherent } \\
\text { with the prescribed } \\
\text { medication(s) for } \\
\text { MDD since the } \\
\text { baseline visit. } \\
\text {-Patients were asked } \\
\text { how regularly they } \\
\text { took the } \\
\text { medications } \\
\text { prescribed for MDD } \\
\text { since the baseline } \\
\text { visit. }\end{array}$ & Self-Report \\
\hline $\begin{array}{l}\text { Serrano et al. } \\
(2014)^{59}\end{array}$ & 6 months & $72.4 \%$ & SMAQ & Self-Report \\
\hline $\begin{array}{l}\text { Shrestha } \\
\text { Manandhar et al. } \\
(2017)^{60}\end{array}$ & 4 months & $37 \%$ & $\begin{array}{l}\text { Structured } \\
\text { questionnaire }\end{array}$ & Self-Report \\
\hline $\begin{array}{l}\text { Taleban et al. } \\
(2016)^{61}\end{array}$ & $\mathrm{NM}$ & $\mathrm{NM}$ & MARS & Self-Report \\
\hline $\begin{array}{l}\text { Vannachavee et } \\
\text { al. }(2016)^{62}\end{array}$ & 3 months & $\begin{array}{l}\text { I: } 41.17 \pm 2.87 ; \mathrm{C}: \\
22.58 \pm 17.07\end{array}$ & SMIR & Self-Report \\
\hline $\begin{array}{l}\text { Bushnell et al. } \\
(2016)^{63}\end{array}$ & 6 months & $45 \%$ & $\begin{array}{l}\text { Non-persistent if } \\
\text { treatment had } \\
\text { been stopped } \\
\text { before } 180 \text { days } \\
\text { after the index } \\
\text { antidepressant's } \\
\text { dispensing date }\end{array}$ & $\begin{array}{l}\text { Medical and } \\
\text { pharmaceutical } \\
\text { Claims Database }\end{array}$ \\
\hline $\begin{array}{l}\text { Green et al. } \\
(2017)^{64}\end{array}$ & $\mathrm{NM}$ & $54 \%$ & Medical Record & Claims Database \\
\hline $\begin{array}{l}\text { Grover et al. } \\
(2018)^{65}\end{array}$ & 1 year & $\begin{array}{l}3 \text { months }(34.3 \%) \\
3-6 \text { months }(25 \%) \\
6-12 \text { months }(10 \%)\end{array}$ & Medical record & Claims Database \\
\hline
\end{tabular}




\begin{tabular}{|c|c|c|c|c|}
\hline Author (year) & $\begin{array}{l}\text { Period of data } \\
\text { collection }\end{array}$ & $\begin{array}{l}\text { Medication } \\
\text { adherence rate } \\
(\mathrm{I}: \mathrm{C})\end{array}$ & $\begin{array}{l}\text { Adherence } \\
\text { measure }\end{array}$ & $\begin{array}{l}\text { Data collection } \\
\text { methods }\end{array}$ \\
\hline $\begin{array}{l}\text { Holvast et al. } \\
(2019)^{66}\end{array}$ & 2 years & $\begin{array}{l}\text { Initiation: } 86.5 \% \\
\text { Optimal } \\
\text { implementation: } \\
84.8 \% \text { Persistence: } \\
62.9 \%\end{array}$ & $\begin{array}{l}\text { Three measures of } \\
\text { non-adherence } \\
\text { (Non-initiation (not } \\
\text { dispensed by the } \\
\text { SFK database } \\
\text { within } 14 \text { days), } \\
\text { suboptimal } \\
\text { implementation } \\
\text { (MPR), } \\
\text { Non-persistence } \\
\text { (discontinuation } \\
\text { within } 294 \text { days } \\
\text { after first dispense)) }\end{array}$ & $\begin{array}{l}\text { Claims Database } \\
\text { electronic medical } \\
\text { records }\end{array}$ \\
\hline $\begin{array}{l}\text { Klang et al. } \\
(2015)^{67}\end{array}$ & 24 weeks & I:55\%; C:15.2\% & $\begin{array}{l}\text { The prescription } \\
\text { fill method to } \\
\text { assess adherence } \\
\text { (the proportion of } \\
\text { compliance during } \\
\text { the first } 24 \text { weeks) }\end{array}$ & Claims Database \\
\hline $\begin{array}{l}\text { LeBlanc et al. } \\
(2015)^{68}\end{array}$ & 2 years & $\mathrm{I}: 67.7 \% ; \mathrm{C}: 65.5 \%$ & $\mathrm{PDC}$ & Claims Database \\
\hline $\begin{array}{l}\text { Slabbert et al. } \\
(2015)^{69}\end{array}$ & 6 years & $34 \%$ & MPR & Claims Database \\
\hline $\begin{array}{l}\text { Zhang et al. } \\
(2016)^{70}\end{array}$ & 1 year & $17.8 \%$ & $\begin{array}{l}\text { The duration of } \\
\text { time from } \\
\text { initiation to } \\
\text { discontinuation of } \\
\text { therapy. }\end{array}$ & Claims Database \\
\hline $\begin{array}{l}\text { Hammonds et al. } \\
(2015)^{71}\end{array}$ & $\begin{array}{l}2 \text { years and } 7 \\
\text { months }\end{array}$ & $45 \%$ & $\begin{array}{l}\text { Percent adherence } \\
\text { was calculated by } \\
\text { dividing the } \\
\text { actual number of } \\
\text { pills taken by the } \\
\text { expected number } \\
\text { of pills taken } \\
\text { during the study } \\
\text { period and } \\
\text { multiplying the } \\
\text { total by } 100\end{array}$ & Pill Count \\
\hline
\end{tabular}




\begin{tabular}{|c|c|c|c|c|}
\hline Author (year) & $\begin{array}{l}\text { Period of data } \\
\text { collection }\end{array}$ & $\begin{array}{l}\text { Medication } \\
\text { adherence rate } \\
\text { (I:C) }\end{array}$ & $\begin{array}{l}\text { Adherence } \\
\text { measure }\end{array}$ & $\begin{array}{l}\text { Data collection } \\
\text { methods }\end{array}$ \\
\hline $\begin{array}{l}\text { Pradeep et al. } \\
(2014)^{72}\end{array}$ & 3 years & $\begin{array}{l}\mathrm{I}: 11.1 \pm 10.4 ; \\
\mathrm{C}: 3.33 \pm 3.79\end{array}$ & $\begin{array}{l}\text { The total number } \\
\text { of weeks the } \\
\text { subjects took } \\
\text { antidepressant } \\
\text { medication, pill } \\
\text { counts to ensure } \\
\text { that patients took } \\
\text { medication as } \\
\text { prescribed by } \\
\text { doctor. }\end{array}$ & Pill count \\
\hline
\end{tabular}

**Note: BMQ; The Brief Medication Questionnaire; C: Control; DAI: Drug Attitude Inventory; MARS: The Medication Adherence Rating Scale; MGLS: Morisky Green Levine Medication Adherence Scale; MMAS: Morisky Medication Adherence Scale; MPR: Medicine Possession Ratio; NM: Not Mention; I: Interventional; PDC: Percentage of Days Covered; SMAQ: Simplified Medication Adherence Questionnaire; SMIR: SelfMedication Intake Record

Table 5 . Factors affecting toward medication adherence $(\mathrm{n}=26)$

\begin{tabular}{lll}
\hline Dimension & Factors in each dimension & Studies \\
\hline Social-economic factors & Cultural beliefs and attitude of & $21,24,25,52,56,57,60,64,65$, \\
& social and family towered mental & 73,74 \\
& disorders and medications Stigma \\
& of social and family towered \\
& mental disorders and medications \\
& Level of education Literacy \\
& Language Social support networks \\
& system (family, friend, spouse, \\
& co-worker) Religion beliefs Income \\
& Employment status (Nature of \\
& the job, occupation of patients) \\
& Living conditions
\end{tabular}




\begin{tabular}{|c|c|c|}
\hline Dimension & Factors in each dimension & Studies \\
\hline $\begin{array}{l}\text { Healthcare } \\
\text { provider/System-related factors }\end{array}$ & $\begin{array}{l}\text { Accessibility to healthcare } \\
\text { services (long distance, lack of } \\
\text { accessible appropriate material, } \\
\text { limited time and long waiting } \\
\text { time at the clinic, and poor access } \\
\text { to healthcare locations) Follow-up } \\
\text { visits system (Frequent or } \\
\text { infrequent follow-ups clinic visits) } \\
\text { Instruction and information about } \\
\text { medications and disorders Change } \\
\text { and multiple prescribers Supply of } \\
\text { medications (availability of } \\
\text { medication, frequent medication } \\
\text { refill) Patient-provider } \\
\text { relationship Availability of } \\
\text { providers }\end{array}$ & $21-25,49,57,64,65$ \\
\hline Illness-related factors & $\begin{array}{l}\text { Onset of the illness Duration of } \\
\text { illness Symptoms and illness } \\
\text { severity Number of psychiatric } \\
\text { hospitalizations Comorbid illness } \\
\text { Suicide ideation and attempts } \\
\text { Family and past history }\end{array}$ & $21-25,34,48,56,57,65,66,73$ \\
\hline Medication-related factors & $\begin{array}{l}\text { Complex treatment regimens } \\
\text { Adverse reactions Duration of } \\
\text { treatment Cost of treatment } \\
\text { Classes of antidepressant }\end{array}$ & $\begin{array}{l}21,24,25,34,48,49,52,57,58 \\
60,62,64-66,69,73,74\end{array}$ \\
\hline Patient-related factors & $\begin{array}{l}\text { Sociodemographic factors Age } \\
\text { Gender Race Marital status } \\
\text { Psychological factors Beliefs } \\
\text { Attitudes Satisfaction Knowledge } \\
\text { Self-management Psychological } \\
\text { reactance Locus of control Insight } \\
\text { Self-stigma Self-motivation } \\
\text { Physical (cognitive and } \\
\text { behavioral) factors Forgetfulness } \\
\text { The patient's personal obligations } \\
\text { Carelessness Confusion }\end{array}$ & $\begin{array}{l}21-25,34,46,48,49,51-53,56 \\
57,59,60,62,64-66,69,73,74\end{array}$ \\
\hline
\end{tabular}

Table 6 . Studies with interventions to medication adherence $(n=10)$ 


\begin{tabular}{llll}
\hline Author (year) & Country & Intervention & Categories \\
\hline $\begin{array}{l}\text { Sirey et al. } \\
(2017)^{19}\end{array}$ & USA & TIP Program & Multi-faceted \\
& & (Cognitive \\
& & education and \\
& & information; and \\
& & behavioral \\
& & counselling)
\end{tabular}

Outcomes

TIP Program is an effective intervention to improve early adherence to pharmacotherapy. Also, interventional group were 5 times more likely to be adherent at 6 weeks and were 3 times more likely to be adherent to their antidepressant pharmacotherapy at both 6 and 12 weeks.

Furthermore, interventional group showed a significant reduction in depressive symptoms. 


\begin{tabular}{llll}
\hline Author $($ year $)$ & Country & Intervention & Categories \\
\hline Aljumah and & Saudi Arabia & Pharmacist & Education and \\
Hassali $(2015)^{47}$ & & interventions & information
\end{tabular}

SDM

Outcomes

Pharmacist

interventions

based on SDM,

intervention

group showed

significant

differences in

adherence to

medication,

treatment

satisfaction,

general overuse

beliefs, specific

concern beliefs,

and total general

beliefs about

medicines.

However, severity

of depression and

quality of live

were not

significantly

change between

intervention and

control group at

the end of six

months. After 6

months,

intervention

group patients

showed

statistically

significant in

adherence to

antidepressants

and treatment

satisfaction, and a

decrease in

concern beliefs

and general

beliefs about

medicines. 


\begin{tabular}{|c|c|c|c|c|}
\hline Author (year) & Country & Intervention & Categories & Outcomes \\
\hline Bhat et al. $(2018)^{49}$ & USA & $\begin{array}{l}\text { A pharmacist-led } \\
\text { multidisciplinary } \\
\text { telemonitoring } \\
\text { service }\end{array}$ & $\begin{array}{l}\text { Multi-faceted } \\
\text { (Education and } \\
\text { information; and } \\
\text { monitor feedback } \\
\text { (adherence and } \\
\text { disease)) }\end{array}$ & $\begin{array}{l}\text { The clinical } \\
\text { pharmacist-led } \\
\text { multidisciplinary } \\
\text { antidepressant } \\
\text { telemonitoring } \\
\text { service is a resource } \\
\text { to monitor patients } \\
\text { after antidepressant } \\
\text { initiation or } \\
\text { uptitration in } \\
\text { primary care } \\
\text { settings and } \\
\text { provided } \\
\text { interventions for } \\
\text { patients. However, } \\
\text { unable to strongly } \\
\text { assess the impact of } \\
\text { clinical pharmacists' } \\
\text { interventions. }\end{array}$ \\
\hline Isa et al. $(2018)^{54}$ & Nigeria & $\begin{array}{l}\text { Psycho-education } \\
\text { and basic CBT } \\
\text { strategies }\end{array}$ & $\begin{array}{l}\text { Multi-faceted } \\
\text { (Cognitive } \\
\text { education and } \\
\text { information; and } \\
\text { behavioral } \\
\text { counselling) }\end{array}$ & $\begin{array}{l}\text { The effect of a } \\
\text { psycho- } \\
\text { educational and } \\
\text { basic CBT } \\
\text { intervention } \\
\text { resulted in } \\
\text { reduction in } \\
\text { depressive } \\
\text { symptoms, } \\
\text { improvements in } \\
\text { knowledge of } \\
\text { depression, hope, } \\
\text { and attitude } \\
\text { towards } \\
\text { treatment } \\
\text { adherence one } \\
\text { week and four } \\
\text { weeks after the } \\
\text { intervention. }\end{array}$ \\
\hline
\end{tabular}




Author (year)

Taleban et al. $(2016)^{61}$

Intervention
Bibliotherapy and
text messaging

Bibliotherapy and

Iran

Country

text messaging

Categories
Counselling
(Cognitive
behavioral
interventions)

Outcomes

Based on

treatment

compliance not significantly affected through group, but factors interactive effect of group factor and the time factor was statistically significant. Neither of the groups showed significant variations of the treatment compliance in different times comprising before the treatment, after the treatment or during the following up procedure. However, intensity of depressive symptoms was significantly affected through time and group factors as well as time-group interaction. Neither of the interventional groups differed in intensity of depressive symptoms. 
Author (year)

Vannachavee et al. $(2016)^{62}$

Klang et al. $(2015)^{67}$
Israel

\begin{tabular}{ll} 
Intervention & Categories \\
\hline DAEP & Multi-faceted \\
& (Motivational \\
& interviewing; and \\
& cognitive and \\
& behavioral \\
& counselling)
\end{tabular}

CPs management

Multi-faceted

(Education and information, reminders, and monitor feedback (adherence and disease))
Outcomes

The participants

in the

experimental group had more correct drug adherence behaviors in terms of the dosage and timing during the sixth week than that of the participants in the control group. Also, the patients who received the DAEP had better depression scores after the intervention than those who received only the usual care.

Measure adherence to antidepressant treatment at 6 months. At 1 month, the adherence rate was $71 \%$ in the $\mathrm{CP}$ group and at 6 months, the rates were high (55\%) than control group of $42 \%$. At 1 month, the adherence rate was $57 \%$ in the control group and at 6 months, the rate was $15.2 \%$. 


\section{Author (year)}

Hammonds et al. $(2015)^{71}$
LeBlanc et al.

$\begin{array}{ll}\text { Country } & \text { Interve } \\ \text { USA } & \text { DMC }\end{array}$
$(2015)^{68}$

USA

(2015)
USA
Electronic

medication

reminder

application
Reminders

Education and information
Outcomes

The use of DMC

by primary care

clinicians and

patients with

moderate to

severe depression

during clinical

encounters was

feasible and

effectively

improved patient

knowledge and

engagement in the

decision-making

process, as well as

patient and

clinician

satisfaction with

that process.

However, use of

the decision aid,

had no discernible

effect on

encounter

duration,

depression

control, and

medication use

and adherence.

Participants use

of a medication

reminder app

were 3.5 times

more likely to

adhere to their

medication

regimen than

those in the

control group.

However,

depression

symptoms were

reduced from

baseline, but the

magnitude of

change was not

greater in

participants using

the medication

reminder app. 


\begin{tabular}{|c|c|c|c|c|}
\hline Author (year) & Country & Intervention & Categories & Outcomes \\
\hline $\begin{array}{l}\text { Pradeep et al. } \\
(2014)^{72}\end{array}$ & India & $\begin{array}{l}\text { Community care } \\
\text { support }\end{array}$ & $\begin{array}{l}\text { Multi-faceted } \\
\text { (Education and } \\
\text { information; and } \\
\text { monitor feedback } \\
\text { (adherence and } \\
\text { disease)) }\end{array}$ & $\begin{array}{l}\text { The number of } \\
\text { clinic related visits } \\
\text { and the duration of } \\
\text { treatment (as } \\
\text { measured by the } \\
\text { number of weeks } \\
\text { that subjects took } \\
\text { antidepressant } \\
\text { medication) was } \\
\text { significantly greater } \\
\text { in the interventional } \\
\text { group compared to } \\
\text { control group. } \\
\text { While there was a } \\
\text { significant difference } \\
\text { in the treatment } \\
\text { adherence pattern } \\
\text { between the two } \\
\text { groups, there was } \\
\text { no significant } \\
\text { difference in the } \\
\text { outcomes of } \\
\text { depression and } \\
\text { quality of life at six } \\
\text { months follow up. }\end{array}$ \\
\hline
\end{tabular}

**Note: CBT: Cognitive Behavioural Therapy; CP: Community pharmacist; DAEP: Drug Adherence Enhancement Program; DMC: Depression Medication Choice; SDM: Shared Based on Decision Making; TIP: The Treatment Initiation and Participation

Figure 1. PRISMA flow diagram of search and selection process 